Boston University School of Law Scholarly Commons at Boston University School of Law

Faculty Scholarship

$10-2015$

\title{
Patent Trolls and Preemption
}

Paul Gugliuzza

Boston University School of Law

Follow this and additional works at: https://scholarship.law.bu.edu/faculty_scholarship

Part of the Intellectual Property Law Commons

\section{Recommended Citation}

Paul Gugliuzza, Patent Trolls and Preemption, 101 Virginia Law Review 1579 (2015).

Available at: https://scholarship.law.bu.edu/faculty_scholarship/88

This Article is brought to you for free and open access by Scholarly Commons at Boston University School of Law. It has been accepted for inclusion in Faculty Scholarship by an authorized administrator of Scholarly Commons at Boston University School of Law. For more information, please contact lawlessa@bu.edu. 


\section{VIRGINIA LAW REVIEW}

\begin{tabular}{lll}
\hline \hline VOLUME 101 & OCTOBER 2015 & NuMBER 6 \\
\hline \hline
\end{tabular}

\section{ARTICLES}

\section{PATENT TROLLS AND PREEMPTION}

\section{Paul R. Gugliuzza*}

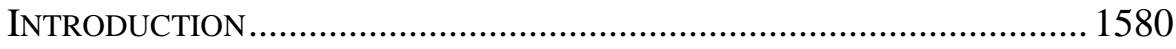

I. PATENT ENFORCEMENT AND STATE LAW.................................... 1588

A. New State Statutes .............................................................. 1590

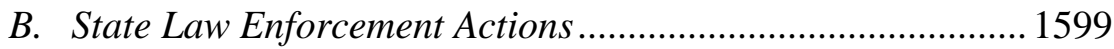

II. PreEMPtion AND Petitioning IMMUnity .................................... 1600

A. Federal Preemption .............................................................. 1601

1. Preemption Generally .................................................... 1601

2. The Supreme Court on Patent Preemption...................... 1603

3. Preemption of State Patent Enforcement Statutes

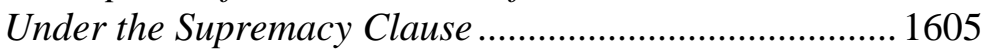

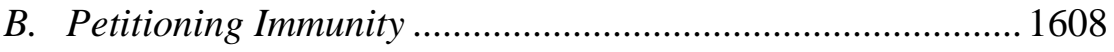

III. The Federal Circuit on PATENT “PREEMPTION”....................... 1616

A. Immunity for Patent Holders ............................................ 1617

\footnotetext{
* Associate Professor, Boston University School of Law. For comments and helpful discussions, thanks to Jonas Anderson, Kent Barnett, Andy Beckerman-Rodau, Brian Carroll, Zach Clopton, Kris Collins, Stacey Dogan, Shubha Ghosh, Wendy Gordon, Mike Harper, Paul Heald, Keith Hylton, Jay Kesan, Megan La Belle, Gary Lawson, Mark Lemley, Gillian Metzger, Mike Meurer, Orly Lobel, Lisa Larrimore Ouellette, Laura Pedraza-Fariña, Rachel Rebouché, Greg Reilly, Matthew Sag, David Schwartz, David Taylor, Fred Tung, David Walker, Melissa Wasserman, Larry Yackle, and Kathy Zeiler. Thanks also to participants at the Junior Faculty Federal Courts Workshop at the University of Georgia School of Law, the Intellectual Property Scholars Conference at UC Berkeley School of Law, the Works-inProgress Intellectual Property Colloquium at the U.S. Patent and Trademark Office, the American Bar Association's Annual Intellectual Property Law Conference, the University of Illinois College of Law Intellectual Property Colloquium, a panel on Intellectual Property and the Courts at the Law and Society Association Annual Meeting, and a faculty workshop at Boston University School of Law. Finally, thanks to Dan Risica for superb research assistance.
} 
1. Equitable Roots of Good Faith Immunity........................1617

2. Good Faith in the Federal Circuit ................................... 1620

B. Equating Bad Faith with Noerr Immunity ............................ 1624

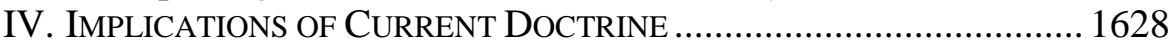

A. A Legal Right to Lie?............................................................... 1629

B. Implications for the New State Statutes and State Law Enforcement Actions........................................................... 1631

C. Implications for Federal Law and Law Enforcement............ 1635

V. Rethinking Petitioning IMMUnity in PATENT CASES ................ 1639

A. Returning to Good Faith..................................................... 1639

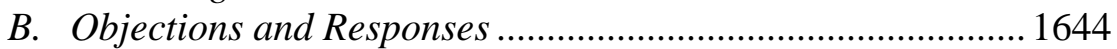

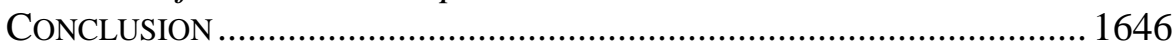

\section{INTRODUCTION}

TN September 2012, eighty-one companies with nonsensical names 1 such as CleOrv, DucPla, and EntNil began sending letters to over 16,000 businesses throughout the United States. ${ }^{1}$ The letters stated that the sender was the "licensing agent" for several U.S. patents that cover the use of an office scanner to send documents via e-mail. ${ }^{2}$ The letters noted that the recipient "almost certainly uses" that technology and that, accordingly, the recipient "should enter into a license agreement with us at this time" at a "fair price" of approximately $\$ 1,200$ per employee. ${ }^{3}$ Many recipients of that letter received two subsequent letters from a Texas-based law firm, Farney Daniels. The first letter noted that the matter had been referred to the firm and that its representation "can involve litigation." " The second letter stated bluntly that "if we do not hear from you within two weeks from the date of this letter, our client will be forced to file a Complaint against you for patent infringement in Federal District Court." ${ }^{5}$ This second letter also included a draft complaint against the recipient. ${ }^{6}$

\footnotetext{
${ }^{1}$ Samples of these letters can be found in a complaint for unfair competition filed by the Federal Trade Commission. See Complaint, MPHJ Tech. Invs., LLC, No. 1423003 (F.T.C. Nov. 6, 2014), available at http://www.ftc.gov/enforcement/cases-proceedings/142-3003/mphjtechnology-investments-llc-matter [hereinafter FTC Complaint].

${ }^{2}$ Id. exhibit A, at 1.

${ }^{3}$ Id. at 4 . Some versions of the letter stated the price as $\$ 1,000$ per employee. FTC Complaint, supra note 1 , $\mathbb{1} 30$, at 7 .

${ }^{4}$ Id. exhibit B, at 1 .

${ }^{5}$ Id. exhibit C, at 1 .

${ }^{6}$ See id.
} 
It turns out that CleOrv, DucPla, EntNil, and the other companies asserting patent infringement are all subsidiaries of another company, MPHJ Technology Investments, which is controlled by a Texas lawyer named Jay Mac Rust. ${ }^{7}$ Patent holders such as MPHJ have been called "bottom feeder" patent trolls: They assert patents against numerous potential infringers, relying on the high cost of threatened litigation to extract quick settlements. ${ }^{8}$ Notably, bottom feeder trolls such as MPHJ have begun to target not the manufacturers of allegedly infringing technology, but the businesses, organizations, and individuals who are the end users of that technology. ${ }^{9}$ For instance, patent trolls have sent letters to thousands of hotels and restaurants, claiming that those businesses committed patent infringement by using wireless technology to make Internet service available to their customers. ${ }^{10}$ Another patent troll sent letters to numerous construction companies claiming infringement of a patent on the use of a "moisture removal system"-that is, a fan-to dry lumber during construction. ${ }^{11}$

These enforcement campaigns are troubling because, if the patents are as broad as their owners claim, they may be invalid due to the Patent Act's requirements of novelty and nonobviousness. ${ }^{12}$ Yet the nature of

\footnotetext{
${ }^{7}$ See Agreement Containing Consent Order \ 2, MPHJ Tech. Invs., LLC, No. 1423003 (F.T.C. Nov. 6, 2014), available at https://www.ftc.gov/system/files/documents/cases/14110 6mphjagree.pdf.

${ }^{8}$ See Mark A. Lemley \& A. Douglas Melamed, Missing the Forest for the Trolls, 113 Colum. L. Rev. 2117, 2126 (2013). There are, of course, terms other than the pejorative "patent troll" that are used to refer to entities that exist primarily to assert patents and that do not manufacture a product or provide services, including "non-practicing entity" ("NPE") and "patent assertion entity" ("PAE”). For an overview of the terminology and a discussion of potential differences in meaning among the terms, see David L. Schwartz \& Jay P. Kesan, Analyzing the Role of Non-Practicing Entities in the Patent System, 99 Cornell L. Rev. 425, 426 (2014); see also Christopher A. Cotropia, Jay P. Kesan \& David L. Schwartz, Unpacking Patent Assertion Entities (PAEs), 99 Minn. L. Rev. 649, 667-70 (2014) (dividing patentholder litigants into eight different categories).

${ }^{9}$ See Gaia Bernstein, The Rise of the End User in Patent Litigation, 55 B.C. L. Rev. 1443, 1456 (2014).

${ }^{10}$ See, e.g., In re Innovatio IP Ventures, LLC Patent Litig., 921 F. Supp. 2d 903, 907 (N.D. Ill. 2013).

${ }^{11}$ Letter from Jon Chandler, Or. Home Builders Ass'n, to Senate Comm. on Judiciary (Feb. 12, 2014), available at https://olis.leg.state.or.us/liz/2014R1/Downloads/CommitteeMeetingDo cument/33881.

${ }^{12}$ See 35 U.S.C. §§ 102, 103 (2012). Indeed, several claims of MPHJ’s patents have been invalidated in post-issuance review proceedings at the Patent and Trademark Office. See, e.g., Ricoh Ams. Corp. v. MPHJ Tech. Invs., LLC, No. IPR2013-302 (P.T.A.B. Nov. 19, 2014); Hewlett-Packard Co. v. MPHJ Tech. Invs., LLC, No. IPR2013-309 (P.T.A.B. Nov. 19, 2014).
} 
the enforcement behavior is also disturbing. Many demand letters are sent to entities, such as nonprofits, municipal governments, and small businesses that are unfamiliar with patent litigation ${ }^{13}$ and that may find it too costly to investigate the merit of the patent claims or to fight the infringement allegations. ${ }^{14}$ Indeed, the letters sent by bottom feeders are designed to intimidate the recipient into quickly purchasing a license. MPHJ's lawyers, for example, threatened to file suit unless the recipient responded within two weeks. ${ }^{15}$ But those threats often are deceptive or false. MPHJ, for instance, did not file a single infringement suit for several months after the final letters were sent, suggesting that it never intended to litigate at all. ${ }^{16}$ When MPHJ finally did file suit, it did so only after numerous state attorneys general had begun investigating the company's enforcement tactics. ${ }^{17}$

In response to these campaigns, legislatures in over half the states have passed statutes outlawing certain acts of patent enforcement. ${ }^{18}$ In a majority of those states, the new laws are modeled after a statute first adopted in Vermont, which prohibits "bad faith" assertions of patent infringement. ${ }^{19}$ Other states have outlawed assertions that "contain false, misleading, or deceptive information" 20 or have defined specific acts as illegal, such as making infringement assertions that "lack a reasonable basis in fact or law" or failing to provide, in a letter alleging patent in-

\footnotetext{
${ }^{13}$ See Colleen Chien \& Edward Reines, Why Technology Customers Are Being Sued En Masse for Patent Infringement and What Can Be Done, 49 Wake Forest L. Rev. 235, 235 (2014).

${ }^{14}$ See James Bessen \& Michael J. Meurer, The Direct Costs from NPE Disputes, 99 Cornell L. Rev. 387, 400 (2014) (noting that NPE litigation is relatively more costly for small firms than for larger firms).

${ }^{15}$ See FTC Complaint, supra note 1, exhibit C, at 1.

${ }^{16}$ Complaint exhibit F, at 12, MPHJ Tech. Invs., LLC v. FTC, No. 6:14-cv-11 (W.D. Tex. Jan. 13, 2014) (excerpting FTC draft complaint against MPHJ), available at http://cdn. arstechnica.net/wp-content/uploads/2014/01/FTC-MPHJ.draf_.complaint.pdf.

${ }^{17}$ See infra Section I.B (discussing state attorney general investigations). Moreover, MPHJ did not sue the small businesses it targeted in the demand letter campaign; it sued large companies such as Coca-Cola, the insurance company Unum Group, and the department store chain Dillard's. Ryan Davis, "Patent Troll” Targets Coca-Cola amid Probe by AGs, Law360 (Jan. 7, 2014), http://www.law360.com/articles/498845.

${ }^{18}$ As of June 2015, twenty-seven states had passed statutes regulating patent enforcement conduct. Those states are: Alabama, Colorado, Florida, Georgia, Idaho, Illinois, Indiana, Kansas, Louisiana, Maine, Maryland, Mississippi, Missouri, Montana, New Hampshire, North Carolina, North Dakota, Oklahoma, Oregon, South Dakota, Tennessee, Texas, Utah, Vermont, Virginia, Washington, and Wisconsin. See infra Section I.A (summarizing the statutes).

${ }^{19}$ Vt. Stat. Ann. tit. 9, § 4197(a) (2014).

${ }^{20}$ Wis. Stat. $\S 100.197(2)(b)$ (2014).
} 
fringement, "factual allegations" about how, exactly, the recipient infringes the patent. ${ }^{21}$ Most of the new statutes create a private right of action for the targets of unlawful infringement assertions and all of the statutes allow for enforcement by state officials, such as the state attorney general. ${ }^{22}$ In addition, state attorneys general have begun to use long-existing state laws, such as consumer protection statutes and deceptive trade practices laws, to challenge schemes of patent enforcement. ${ }^{23}$

Although patents are usually thought to be the domain of the federal government alone, ${ }^{24}$ Congress has only recently begun to consider bills that would outlaw unfair or deceptive patent demand letters. ${ }^{25}$ The states' growing role in the patent system is reflected on the website of the U.S. Patent and Trademark Office, which counsels persons who receive demand letters that are "deceptive, predatory, or in bad faith" to, among other things, "fil[e] a complaint with your state attorney general's office.” ${ }^{26}$ The states, by taking aggressive steps to regulate patent enforcement, are thus poised to erode the federal government's monopoly over the patent system.

Doctrines of federal constitutional law, however, may invalidate the new state statutes and limit the law enforcement authority of state officials. For decades, businesses and individuals accused of patent infringement have tried to assert state law tort claims against overzealous patent holders, but the U.S. Court of Appeals for the Federal Circuit, which has exclusive appellate jurisdiction over patent cases, ${ }^{27}$ has held that those claims are mostly preempted by the federal Patent Act. According to the Federal Circuit, to avoid preemption, the accused infringer must prove not only the elements of its state law claim, it must also prove, by clear and convincing evidence, (1) that the patent holder's infringement allegations were "objectively baseless," meaning that no reasonable litigant could have expected to succeed, and (2) that the patent holder made its infringement allegations with knowledge of their inaccu-

\footnotetext{
${ }^{21}$ See, e.g., Tenn. Code Ann. § 29-10-102(a)(3) (2014).

${ }^{22}$ See infra notes 84-86, 107, 121 and accompanying text.

${ }^{23}$ See infra Section I.B.

${ }^{24}$ See Paul R. Gugliuzza, Patent Law Federalism, 2014 Wis. L. Rev. 11, 12.

${ }^{25}$ See infra Section IV.C.

${ }^{26}$ I Got a Letter ... , U.S. Patent \& Trademark Office (Jan. 30, 2014, 3:53 PM), http:// www.uspto.gov/patents/litigation/I_got_a_letter.jsp.

${ }^{27}$ See generally Paul R. Gugliuzza, Rethinking Federal Circuit Jurisdiction, 100 Geo. L.J. 1437, 1441-42 (2012).
} 
racy or with reckless disregard for their accuracy. ${ }^{28}$ Cases challenging the constitutionality of the new state statutes and state law enforcement actions are just getting underway. ${ }^{29}$ But the Federal Circuit's two-part test will almost certainly prohibit the states from condemning any but the most frivolous assertions of patent infringement. ${ }^{30}$ This Article argues, however, that the Federal Circuit's preemption rule is wrong as a matter of doctrine, is misguided as a matter of policy, and ignores important lessons from the history of patent enforcement.

As a matter of doctrine, courts usually identify the Constitution's Supremacy Clause as the source of preemption law, ${ }^{31}$ and the Federal Circuit has sometimes invoked the Supremacy Clause as grounds for immunizing acts of patent enforcement from state law liability. ${ }^{32}$ A closer examination of Federal Circuit case law, however, reveals that the most significant constitutional barrier to state regulation of patent enforcement is not preemption pursuant to the Supremacy Clause; it is the Federal Circuit's erroneous interpretation of the First Amendment's Petition Clause. ${ }^{33}$

Under an orthodox, Supremacy Clause-based preemption analysis, state laws regulating patent enforcement likely avoid preemption. Although the state laws create some disuniformity in the patent system, they arguably do not conflict with the core objectives of federal patent

${ }^{28}$ Globetrotter Software, Inc. v. Elan Computer Grp., 362 F.3d 1367, 1377 (Fed. Cir. 2004); Golan v. Pingel Enter., Inc., 310 F.3d 1360, 1371 (Fed. Cir. 2002).

${ }^{29}$ See MPHJ Tech. Invs. LLC v. Sorrell, No. 2:14-cv-191, 2015 WL 3505224, at *9 (D. Vt. June 3, 2015) (denying the state's motion to dismiss in a suit seeking a declaratory judgment that the Vermont statute is unconstitutional).

${ }^{30}$ For commentary raising the possibility that the pathmarking Vermont statute is preempted, see David Lee Johnson, Note, Facing Down the Trolls: States Stumble on the Bridge to Patent-Assertion Regulation, 71 Wash. \& Lee L. Rev. 2023, 2027 (2014); Adam Smith, Note, Patent Trolls-An Overview of Proposed Legislation and a Solution That Benefits Small Businesses and Entrepreneurs, 9 Ohio St. Entrepreneurial Bus. L.J. 201, 223 (2014); Eric Goldman, Vermont Enacts the Nation’s First Anti-Patent Trolling Law, Forbes (May 22, 2013, 2:22 PM), http://www.forbes.com/sites/ericgoldman/2013/05/22/vermontenacts-the-nations-first-anti-patent-trolling-law.

${ }^{31}$ See, e.g., Cipollone v. Liggett Grp., 505 U.S. 504, 516 (1992); see also U.S. Const. art. VI, cl. 2 ("This Constitution, and the Laws of the United States which shall be made in Pursuance thereof . . . shall be the supreme Law of the Land; and the Judges in every State shall be bound thereby, any Thing in the Constitution or Laws of any State to the Contrary notwithstanding.”).

${ }^{32}$ See, e.g., Hunter Douglas, Inc. v. Harmonic Design, Inc., 153 F.3d 1318, 1338 (Fed. Cir. 1998).

${ }^{33}$ The Petition Clause protects "the right of the people . . . to petition the Government for a redress of grievances.” U.S. Const. amend. I. 
law, such as incentivizing invention and inducing the disclosure of inventions. ${ }^{34}$ And it is difficult to say that federal law fully occupies the field of patent-enforcement regulation: The Patent Act is entirely silent on the issue of unfair or deceptive enforcement-it neither condemns nor immunizes it. ${ }^{35}$ Moreover, courts have consistently refused to find field preemption of state law tort claims that impose liability on patent holders. $^{36}$ Rather than analyzing preemption under the Supremacy Clause, however, the Federal Circuit has imported as its preemption test the nearly insurmountable requirements imposed by the Supreme Court on plaintiffs who seek to inflict antitrust liability on defendants based on those defendants' pursuit of litigation. ${ }^{37}$ This doctrine, often called the Noerr-Pennington doctrine (or Noerr doctrine, for short), ${ }^{38}$ stems from the Supreme Court's interpretation of the federal antitrust statute, the Sherman Act, in the light of the First Amendment's Petition Clause. ${ }^{39}$

To strip an antitrust defendant of the immunity conferred by the Noerr doctrine, the plaintiff must show that the defendant's underlying lawsuit was a "sham" by proving both that the lawsuit was objectively baseless and that it was filed with the subjective intent to impair competition. $^{40}$ The Federal Circuit, in adopting as its preemption rule the same requirements of objective baselessness and subjective bad intent, has thus expanded Noerr immunity by allowing patent holders to invoke the doctrine to avoid any type of civil liability, not just liability under the antitrust laws, based on any conduct related to patent enforcement, not just the pursuit of litigation. ${ }^{41}$ This expansion of Noerr immunity is a mistake. Letters sent from one private party to another, such as letters threatening patent infringement litigation, are not "petition[s]" to "the government" within the meaning of the First Amendment. Moreover, the

\footnotetext{
${ }^{34}$ See infra notes 158-64 and accompanying text.

${ }^{35}$ See infra notes $165-72$ and accompanying text.

${ }^{36}$ See infra notes $173-75$ and accompanying text.

${ }^{37}$ See Globetrotter Software, Inc. v. Elan Computer Grp., 362 F.3d 1367, 1377 (Fed. Cir. 2004).

38 The doctrine's name stems from the cases in which the Supreme Court first developed it. See E. R.R. Presidents Conference v. Noerr Motor Freight, Inc., 365 U.S. 127 (1961); United Mine Workers of Am. v. Pennington, 381 U.S. 657 (1965).

${ }^{39}$ See FTC v. Superior Court Trial Lawyers Ass'n, 493 U.S. 411, 424 (1990).

${ }^{40}$ See Prof'l Real Estate Investors, Inc. v. Columbia Pictures Indus., Inc., 508 U.S. 49, 60 61 (1993).

${ }^{41}$ See Globetrotter, 362 F.3d at 1376. The Federal Circuit, it should be noted, is not alone among the federal courts in applying Noerr beyond its original context. See infra text accompanying notes 193-200.
} 
Federal Circuit's use of Noerr as a preemption rule gets the federalism analysis exactly backwards. The Supreme Court has often articulated a presumption against preemption, ${ }^{42}$ but the Federal Circuit insists that a patent holder seeking to avoid preemption "has a heavy burden to carry." 43

The Federal Circuit's erroneous expansion of Noerr immunity is not only wrong as a matter of doctrine, it also has several destructive policy implications. For instance, it grants patent holders a license to lie in their demand letters, so long as those letters also contain objectively plausible allegations of infringement. Thus, patent holders can lawfully send letters stating that many recipients have already purchased licenses to the asserted patents even if, in fact, few if any recipients have done so. ${ }^{44}$ And patent holders can lawfully claim that the validity of the asserted patents have been upheld in court or in reexamination at the Patent and Trademark Office, even if that is not true. ${ }^{45}$ In addition, because the Federal Circuit purports to derive its Noerr-based immunity standard from the First Amendment, ${ }^{46}$ that standard makes it unconstitutional for not just states but also the federal government to condemn any but the most fantastical allegations of patent infringement. Thus, although the President, members of Congress, and the Federal Trade Commission have all recently voiced concerns about "patent trolls," ${ }^{47}$ Federal Circuit law significantly limits the regulatory options.

Fortunately, history provides a useful lesson on how courts can strike an appropriate balance between protecting patent holders from liability when they make legitimate allegations of infringement and punishing patent holders when they engage in unfair or deceptive enforcement tactics. Specifically, a long line of federal judicial decisions-which the Federal Circuit has mostly ignored-addresses the precise question of when a patent holder may be held liable for its enforcement conduct. As

\footnotetext{
${ }^{42}$ See, e.g., Altria Grp. v. Good, 555 U.S. 70, 77 (2008).

43800 Adept, Inc. v. Murex Sec., Ltd., 539 F.3d 1354, 1370 (Fed. Cir. 2008).

${ }^{44}$ See In re Innovatio IP Ventures, LLC Patent Litig., 921 F. Supp. 2d 903, 920-21 (N.D. Ill. 2013).

${ }^{45}$ See id.

${ }^{46}$ See Globetrotter, 362 F.3d at 1377.

${ }^{47}$ See, e.g., Sen. Patrick Leahy \& Sen. Mike Lee, America's Patent Problem, Politico (Sept. 15, 2013, 9:25 PM), http://politi.co/16vXntz; Edward Wyatt, F.T.C. Votes for Inquiry Into Patent Businesses, N.Y. Times, Sept. 27, 2013, at B1, available at http://www. nytimes.com/2013/09/28/business/ftc-targets-patent-companies.html; Edward Wyatt, Obama Orders Regulators to Root Out "Patent Trolls,” N.Y. Times, June 4, 2013, at B1, available at http://www.nytimes.com/2013/06/05/business/president-moves-to-curb-patent-suits.html.
} 
early as the nineteenth century, courts sitting in equity enjoined patent holders from making infringement assertions in bad faith, which could be established through evidence of the patent holder's "malicious intent." ${ }^{48}$ Although a patent holder's intent is a subjective question, courts often inferred subjective intent from objective evidence, such as the patent holder's threatening a large number of accused infringers ${ }^{49}$ and the patent holder's failure to follow its threats with actual lawsuits. ${ }^{50}$ This flexible, equity-based immunity standard — as opposed to the rigid twopart test mandated by the Federal Circuit-would empower all three branches of government at both the state and federal levels to impose reasonable restrictions on patent enforcement. At the same time, cases in which enforcement conduct was enjoined under the traditional standard were usually egregious and often involved claims that were objectively weak on the merits, ${ }^{51}$ so a revitalized good faith immunity doctrine would protect patent holders' ability to provide legitimate notice of their patent rights.

This Article is the first to consider whether the new state statutes are constitutional. ${ }^{52}$ By showing how current Federal Circuit doctrine could

\footnotetext{
${ }^{48}$ E.g., Emack v. Kane, 34 F. 46, 50-51 (C.C.N.D. Ill. 1888).

${ }^{49}$ E.g., Int'l Indus. \& Devs., v. Farbach Chem. Co., 241 F.2d 246, 247-48 (6th Cir. 1957).

${ }^{50}$ E.g., Adriance, Platt \& Co. v. Nat'l Harrow Co., 121 F. 827, 829-30 (2d Cir. 1903).

${ }^{51}$ E.g., Emack, 34 F. at 49.

${ }^{52} \mathrm{~A}$ few recent student notes have reached conflicting conclusions about whether Vermont's new statute survives under the Federal Circuit's Noerr-based "preemption" law. Compare Johnson, supra note 30, at 2028 (arguing that "much of [Vermont's] law is likely dead letter"), with Ryan DeSisto, Note, Vermont vs. the Patent Troll: Is State Action a Bridge Too Far?, 48 Suffolk U. L. Rev. 109, 126-27 (2015) (noting that the Vermont statute "successfully dodges intrusion upon Congress's exclusive jurisdiction," but that the "objective baselessness" requirement renders the statute "impotent in the great bulk of patenttrolling cases"), and T. Christian Landreth, Recent Development, The Fight Against "Patent Trolls:” Will State Law Come to the Rescue?, 15 N.C. J.L. \& Tech. Online 100, 120 (2014), http://ncjolt.org/wp-content/uploads/2014/01/Landreth_final.pdf (arguing that "Vermont has tailored its statute sufficiently to comply with" Federal Circuit law). Those pieces do not, however, engage the underlying question of whether Noerr provides the correct test for the constitutional validity of laws regulating patent enforcement, nor do they address the implications of current Federal Circuit doctrine for the federal government's efforts to fight unfair or deceptive conduct in patent enforcement. Although few commentators have analyzed the constitutionality of state laws governing patent enforcement, there is a rich literature examining federal preemption of state laws that create intellectual property rights, such as the law of trade secrets, and state laws that have the potential to alter the scope of federal intellectual property rights, such as the law of contracts. As a small sample, see Dan L. Burk, Protection of Trade Secrets in Outer Space Activity: A Study in Federal Preemption, 23 Seton Hall L. Rev. 560, 562-63 (1993); Jeanne C. Fromer, The Intellectual Property Clause's Preemptive Effect, in Intellectual Property and the Common Law 265, 266 (Shyamkrishna Balganesh
} 
quash those innovative reforms, and by offering an alternative to the Federal Circuit's onerous Noerr-based immunity rule, this Article contributes to an important and on-going policy conversation as additional states, as well as the federal government, contemplate steps to fight abusive patent enforcement. ${ }^{53}$

This Article will begin in Part I by outlining the state laws relevant to patent enforcement, including the new state statutes. Part II will then explore the bodies of federal law that potentially nullify those state laws, namely, preemption doctrine under the Supremacy Clause and doctrines of petitioning immunity derived from the First Amendment. Part III will reexamine the relevant Federal Circuit case law, showing that the key limit on the states' ability to regulate patent enforcement is not preemption but the Federal Circuit's flawed interpretation of the First Amendment. Part IV will explore the practical consequences of conferring broad immunity on patent holders' assertions of infringement, highlighting the limited power that both state governments and the federal government have under Federal Circuit law. Finally, Part V will outline ways in which Federal Circuit law should be reformed to provide governments the ability to outlaw unfair and deceptive schemes of patent enforcement.

\section{PATENT ENFORCEMENT AND STATE LAW}

Although the substance of patent law is exclusively federal, ${ }^{54}$ state law is relevant to patents in several areas. Perhaps most notably, owner-

ed., 2013); Paul Heald, Federal Intellectual Property Law and the Economics of Preemption, 76 Iowa L. Rev. 959, 961 (1991); Mark A. Lemley, Beyond Preemption: The Law and Policy of Intellectual Property Licensing, 87 Calif. L. Rev. 111, 114 (1999); Maureen A. O’Rourke, Drawing the Boundary Between Copyright and Contract: Copyright Preemption of Software License Terms, 45 Duke L.J. 479, 479 (1995); Joan E. Schaffner, Patent Preemption Unlocked, 1995 Wis. L. Rev. 1081, 1082-83.

${ }^{53}$ For regularly updated lists of state legislative actions, see 2015 Patent Trolling Legislation, Nat'l Conference of State Legislatures, http://www.ncsl.org/research/financialservices-and-commerce/2015-patent-trolling-legislation.aspx (last visited June 19, 2015); Patent Progress's Guide to State Patent Legislation, Patent Progress, http://www.patent progress.org/patent-progresss-guide-state-patent-legislation (last visited June 19, 2015). For a discussion of proposed federal legislation and potential federal law enforcement actions, see infra Section IV.C.

${ }^{54}$ See 35 U.S.C. §§ 1-376 (2012); Camilla A. Hrdy, State Patent Laws in the Age of Laissez Faire, 28 Berkeley Tech. L.J. 45, 47 (2013) (“Today patent law is purely a federal creature.”). But cf. Camilla A. Hrdy, Dissenting State Patent Regimes, 3 IP Theory 78, 89 (2013), 
ship of a patent is determined by state law. ${ }^{55}$ For example, agreements to assign or license a patent are generally governed by state contract law, ${ }^{56}$ state family law determines who owns a patent after divorce, ${ }^{57}$ and state probate law determines who owns a patent after its owner dies. ${ }^{58}$ In addition, and of most relevance to this Article, activities that patent holders undertake in the process of enforcing their patents may expose them to civil liability under state law.

The enforcement activities that can expose a patent holder to liability include filing and pursuing infringement litigation in court, threatening an accused infringer with an infringement suit, and communicating allegations of infringement to third parties, such as the accused infringer's customers. In those scenarios, the target of the infringement allegations may seek relief under various bodies of state law including unfair competition, ${ }^{59}$ interference with contract or prospective business advantage, ${ }^{60}$ abuse of process, ${ }^{61}$ business disparagement, ${ }^{62}$ and anti-

http://www.repository.law.indiana.edu/ipt/vol3/iss2/2 (suggesting that state governments retain the power to issue patents).

${ }^{55}$ The separate issue of inventorship is governed by federal law. See Univ. of Colo. Found., Inc. v. Am. Cyanamid Co., 196 F.3d 1366, 1372 (Fed. Cir. 1999). The Patent Act requires a patent application to be filed in the names of the natural person or persons who were the actual inventors. See 35 U.S.C. § 111(a)(1). Although the inventors, by default, own the patent, ownership can be transferred by contract, and those contracts are usually governed by state law. See 8 Donald S. Chisum, Chisum on Patents § 22.02 (2009).

${ }^{56}$ See, e.g., Mars, Inc. v. Coin Acceptors, Inc., 527 F.3d 1359, 1370 (Fed. Cir. 2008). For commentary criticizing how the Federal Circuit has applied this rule in practice, see Shubha Ghosh, Short-Circuiting Contract Law: The Federal Circuit's Contract Law Jurisprudence and IP Federalism, 96 J. Pat. \& Trademark Off. Soc’y 536, 551 (2014) (arguing that “[w]hen contract issues intersect with patent law in areas such as licensing and assignments ... the Federal Circuit has used its jurisdiction over patent claims to create a body of contract doctrine that is divorced from state law").

${ }^{57}$ See, e.g., Enovsys LLC v. Nextel Commc’ns Inc., 614 F.3d 1333, 1342 (Fed. Cir. 2010).

${ }^{58}$ See, e.g., Stickle v. Heublein, Inc., 716 F.2d 1550, 1557-58 (Fed. Cir. 1983).

${ }^{59}$ See, e.g., Hunter Douglas, Inc. v. Harmonic Design, Inc., 153 F.3d 1318, 1322 (Fed. Cir. 1998). As the Restatement (Third) of Unfair Competition explains, "the term 'unfair competition' ... describes an array of legal actions addressing methods of competition that improperly interfere with the legitimate commercial interests of other sellers in the marketplace," including "passing off, deceptive advertising, and the infringement of trademarks, trade secrets, and publicity rights.” Restatement (Third) of Unfair Competition, at xi (1995).

${ }^{60}$ See, e.g., Dow Chem. Co. v. Exxon Corp., 139 F.3d 1470, 1477 (Fed. Cir. 1998).

${ }^{61}$ See, e.g., Carroll Touch, Inc. v. Electro Mech. Sys., Inc., 15 F.3d 1573, 1581 (Fed. Cir. 1993).

${ }^{62}$ See, e.g., Additive Controls \& Measurement Sys., Inc. v. Flowdata, Inc., 986 F.2d 476, 478 (Fed. Cir. 1993). Disparagement sometimes goes by the names of injurious falsehood or trade libel. See Black’s Law Dictionary 570 (10th ed. 2014). 
trust, ${ }^{63}$ among others. The target of infringement allegations can also pursue claims under federal law, including antitrust claims under the Sherman Act, ${ }^{64}$ unfair competition claims under the Lanham Act, ${ }^{65}$ and even claims under the civil RICO statute. ${ }^{66}$

There is a long history of parties accused of infringement suing or counterclaiming against the patent holder to challenge the veracity of or motivation behind the infringement allegations. ${ }^{67}$ In the past few years, however, as the term "patent troll" entered the vernacular ${ }^{68}$ and patent holders such as MPHJ began to target end users of patented technology, legislatures in several states have adopted new statutes to deter and punish certain acts of patent enforcement, and state law enforcement officials have also become involved in patent disputes.

\section{A. New State Statutes}

Statutes outlawing particular acts of patent enforcement are actually nothing new. In 1883, the British Parliament created a so-called threats action - a civil claim that could be pursued by persons targeted with groundless threats of suit for patent infringement. ${ }^{69}$ The U.S. patent laws, however, have never provided such a claim. Rather, the statute passed in Vermont in May 2013 was the first statute in the United States to specifically condemn acts of patent enforcement.

Vermont's statute seems, by all accounts, to have been the product of a grassroots effort by businesses and nonprofits in the state who had re-

\footnotetext{
${ }^{63}$ See, e.g., Eon Labs., Inc. v. SmithKline Beecham Corp., 298 F. Supp. 2d 175, 177 (D. Mass. 2003).

${ }^{64}$ See, e.g., Nobelpharma AB v. Implant Innovations, Inc., 141 F.3d 1059, 1068 (Fed. Cir. 1998).

${ }^{65}$ See, e.g., Zenith Elecs. Corp. v. Exzec, Inc., 182 F.3d 1340, 1354 (Fed. Cir. 1999).

${ }^{66}$ See, e.g., Semiconductor Energy Lab. Co. v. Samsung Elecs. Co., 204 F.3d 1368, 1372 (Fed. Cir. 2000) (also involving claims under a state RICO statute).

${ }^{67}$ For an early example of an antitrust claim based on patent enforcement conducted "maliciously and without probable cause," see Virtue v. Creamery Package Manufacturing Co., 227 U.S. 8, 29 (1913), in which the plaintiffs alleged that their "business was destroyed by defendants wrongfully prosecuting two suits against them for the infringement of patents ... and by circulating slanders and libels to the effect that [the plaintiffs'] articles were infringements of defendants' patents.” Id. at 24.

${ }^{68}$ See, e.g., GPNE Corp. v. Apple, Inc., No. 12-cv-2885, slip. op. at 2 (N.D. Cal. June 24, 2014) (Koh, J.) (pre-trial order prohibiting Apple from referring to the plaintiff as, among other things, a "patent troll," "pirate," "bounty hunter," "privateer," "bandit,” or "corporate shell").

${ }^{69}$ See The Law Commission, Patents, Trade Marks and Design Rights: Groundless Threats, 2014, at 13 (U.K.).
} 
ceived demand letters from bottom feeders such as MPHJ. ${ }^{70}$ Those organizations, working with the state's legislators and attorney general, crafted a statute that has served as a model for several other states. ${ }^{71}$

The core provision of the Vermont statute states, simply: "A person shall not make a bad faith assertion of patent infringement."72 The statute then lists several factors that courts "may consider ... as evidence that a person has made a bad faith assertion of patent infringement,"73 including:

- The demand letter ${ }^{74}$ does not contain the patent number, the name and address of the patent holder, and "factual allegations concerning the specific areas in which the target's products, services, and technology infringe the patent." 75

\footnotetext{
${ }^{70}$ See Kristopher A. Boushie et al., The Great Patent Troll Debate-2 Perspectives: Part I, Law360 (May 13, 2014), http://www.law360.com/articles/533838/the-great-patent-troll-debate2-perspectives-part-1.

${ }^{11}$ See Timothy B. Lee, How Vermont Could Save the Nation from Patent Trolls, Wash. Post The Switch (Aug. 1, 2013), http://www.washingtonpost.com/blogs/the-switch/wp/2013/ 08/01/how-vermont-could-save-the-nation-from-patent-trolls (last visited Aug. 14, 2015). The states that have followed Vermont's model include Alabama, Colorado, Florida, Georgia, Idaho, Indiana, Louisiana, Maine, Maryland, Missouri, New Hampshire, North Carolina, North Dakota, Oregon, South Dakota, Utah, Virginia, and Washington. See Ala. Code §§ 354-400 to -406 (LexisNexis 2014); 2015 Colo. Sess. Laws 1263-68 (to be codified at Colo. Rev. Stat. §§ 6-12-101 to -104); H.B. 439, 2015 Leg., at 1-12 (Fla. 2015) (enacted) (to be codified at Fla. Stat. §§ 501.991-97); Ga. Code Ann. §§ 10-1-770 to -774 (2014); Idaho Code Ann. §§ 48-1701 to -1708 (2014); 2015 Ind. Acts 1845-49 (to be codified at Ind. Code $\S \S 24-11-1-1$ to 24-11-5-2); La. Rev. Stat. Ann. § 51:1428 (2015); Me. Rev. Stat. tit. 14, $\S \S 8701-02$ (2014); Md. Code Ann., Com. Law §§ 11-1601 to -1605 (LexisNexis 2014); Mo. Rev. Stat. §§ 416.650-58 (2014); N.H. Rev. Stat. Ann. §§ 359-M:1 to -M:5 (LexisNexis 2014); N.C. Gen. Stat. Ann. §§ 75-140 to -145 (West 2014); N.D. Cent. Code §§ 51-36-01 to -08 (2015); 2014 Or. Laws 2545; S.D. Codified Laws §§ 37-36-1 to -9 (2014); Utah Code Ann. §§ 78B-6-1901 to -1905 (LexisNexis 2014); Va. Code Ann. §§ 59.1-215.1 to .4 (2014); S. 5059, 64th Leg., Reg. Sess. (Wash. 2015) (enacted).

${ }^{72}$ Vt. Stat. Ann. tit. 9, § 4197(a) (2014).

73 Id. § 4197(b).

${ }^{74}$ The statute defines "demand letter" as "a letter, e-mail, or other communication asserting or claiming that the target has engaged in patent infringement.” Id. § 4196(1). The statute defines "target" as a person "who has received a demand letter or against whom an assertion or allegation of patent infringement has been made," "who has been threatened with litigation or against whom a lawsuit has been filed alleging patent infringement," or "whose customers have received a demand letter asserting that the person's product, service, or technology has infringed a patent.” Id. § 4196(2).

${ }^{75}$ Id. § 4197(b)(1).
} 
- The demand letter lacks the information noted above, the target requests the information, and the patent holder fails to provide the information "within a reasonable period of time."76

- The patent holder has previously filed or threatened to file one or more similar patent infringement lawsuits and those threats lacked the information noted above or were found by a court to be meritless. $^{77}$

- Prior to sending the demand letter, the patent holder did not conduct an analysis comparing the claims of the patent to the target's products, services, or technology, "or such an analysis was done but does not identify specific areas in which the products, services, and technology are covered by the claims in the patent."78

- The demand letter demands payment of a license or a response "within an unreasonably short period of time.,"79

- The patent holder "offers to license the patent for an amount that is not based on a reasonable estimate of the value of the license." 80

- "The claim or assertion of patent infringement is meritless, and the person knew, or should have known, that the claim or assertion is meritless." 81

- "The claim or assertion of patent infringement is deceptive." ${ }^{82}$

\footnotetext{
${ }^{76}$ Id. § 4197(b)(3).

${ }^{77}$ Id. $\S 4197(\mathrm{~b})(8)$.

${ }^{78}$ Id. $\S 4197(b)(2)$.

${ }^{79}$ Id. § 4197(b)(4).

${ }^{80}$ Id. § 4197(b)(5).

${ }^{81}$ Id. § 4197(b)(6).

${ }^{82}$ Id. § 4197(b)(7). The statute also lists several factors that courts "may consider . . as evidence that a person has not made a bad faith assertion of patent infringement." Id. $\S 4197$ (c) (emphasis added). Several of the factors are simply the opposite of the factors indicating bad faith. E.g., id. § 4197(c)(6) ("The person has demonstrated good faith business practices in previous efforts to enforce the patent... or successfully enforced the patent ... through litigation.”). Other factors, however, identify specific categories of patent holders for special treatment, making clear the statute's aim at non-practicing entities, e.g., id. § 4197(c)(4) (indicative of good faith if the sender "makes a substantial investment in the use of the patent or in the production or sale of a product or item covered by the patent"), and the political power of certain patent owners, e.g., id. § 4197(c)(5)(B) (indicative of good faith if the sender "is an institution of higher education or a technology transfer organization owned or affiliated with an institution of higher education”).
} 
By instructing courts to determine bad faith by referencing factors that are both objective (for example, that the claim of infringement was meritless) and subjective (for example, that the patent holder knew the claim of infringement was meritless), Vermont has tried to accommodate the Federal Circuit's Noerr-based immunity standard. As discussed in more detail below, however, certain applications of the statute may still be unconstitutional under current Federal Circuit law. ${ }^{83}$

In terms of enforcement, the Vermont statute empowers the state attorney general to instigate both civil investigations and civil actions in court. $^{84}$ The statute also creates a private right of action for the target of a bad faith assertion of patent infringement. ${ }^{85}$ In that private action, a successful plaintiff may obtain equitable relief, damages, costs and attorneys' fees, and "exemplary damages" of $\$ 50,000$ or "three times the total of damages, costs, and fees, whichever is greater." ${ }^{\text {" }}$ In September 2013, the influential Council of State Governments approved Vermont's statute to be included in its compilation of suggested state legislation. ${ }^{87}$

Although over a dozen states have mimicked Vermont's statute by outlawing bad faith assertions of patent infringement, ${ }^{88}$ there are some differences among the statutes adopted in those states. For instance, some states have not created a private right of action, limiting enforcement power to state officials, such as the attorney general. ${ }^{89}$ Also, not all states explicitly permit plaintiffs to recover exemplary or punitive damages. ${ }^{90} \mathrm{~A}$ few statutes outlaw only bad faith assertions made against end

\footnotetext{
${ }^{83}$ See infra Section IV.B.

${ }^{84}$ Vt. Stat. Ann. tit. 9, § 4199(a).

${ }^{85}$ Id. § 4199(b).

${ }^{86} \mathrm{Id}$.

${ }^{87}$ Comm. on Suggested State Legislation Docket 35A, Council of State Gov'ts, Minutes at 5 (Sept. 19-20, 2013), http://www.csg.org/programs/policyprograms/documents/MeetingMinutesDocket35AKansasCity.pdf.

${ }^{88}$ See supra note 71 (listing the states).

${ }^{89}$ See, e.g., 2015 Colo. Sess. Laws 1266 (to be codified at Colo. Rev. Stat. § 6-12-104(1)); La. Rev. Stat. § 51:1428(C)(1) (2015); Va. Code Ann. § 59.1-215.3.E (2014); S. 5059, 64th Leg., Reg. Sess. ch. 108, § 4 (Wash. 2015) (enacted).

${ }^{90}$ See N.H. Rev. Stat. Ann. § 359-M:4.II (LexisNexis 2014) (providing that a plaintiff may obtain equitable relief, damages, and costs and fees, including reasonable attorneys' fees); see also Mo. Rev. Stat. § 416.654 (2014) (permitting recovery of actual damages or $\$ 10,000$ for each violation, whichever is greater, plus attorneys' fees).
} 
users $^{91}$ and other statutes prohibit bad faith assertions only when they are made by nonpracticing entities. ${ }^{92}$

For the purpose of this Article, the most important differences among the statutes involve the conduct that can provide evidence of bad faith. Some statutes, in tension with the Federal Circuit's requirement that a plaintiff challenging patent enforcement conduct must show both objective baselessness and the patent holder's improper subjective intent, grant courts leeway to find bad faith based solely on subjective considerations. The Virginia and Idaho statutes, for instance, indicate that a finding of bad faith may be warranted if an infringement assertion is made "in subjective bad faith" or "a reasonable actor in the [patent holder's] position would know or reasonably should know that [the] assertion is baseless." 93 The Virginia statute also suggests that a finding of bad faith may be appropriate if "the person threatens legal action that ... is not intended to be taken." 94 Current Federal Circuit doctrine plainly prohibits a state from imposing liability based solely on the patent holder's subjective intent, as seems to be possible under the Idaho and Virginia statutes. ${ }^{95}$

In addition to the Vermont-style statutes outlawing bad faith assertions of infringement, there are two other legislative models for regulating patent enforcement: one passed only in Wisconsin, which outlines in detail the information that a demand letter must contain and outlaws false and deceptive assertions of infringement, and another passed in

\footnotetext{
${ }^{91}$ See La. Rev. Stat. § 51:1428(A)(2), (B)(1) (defining “end-user” as “a consumer, whether an individual, business, or financial institution, who purchases, rents, leases, or otherwise obtains a product, service, or technology in the commercial market that is not for resale and is, or later becomes, the subject of a patent infringement assertion”); accord 2015 Colo. Sess. Laws 1264-65 (to be codified at Colo. Rev. Stat. §§ 6-12-101(2), 6-12-102(1)).

${ }^{92}$ See 2015 Colo. Sess. Laws 1266 (to be codified at Colo. Rev. Stat. § 6-12-103(2)(a)); N.C. Gen. Stat. Ann. §§ 75-142(5), -143(c)(4) (2014); N.D. Cent. Code § 51-36-08(2) (2015).

${ }^{93}$ Va. Code Ann. § 59.1-215.2.B.5 (2014); accord Idaho Code Ann. § 48-1703(f) (2014). Interestingly, the Missouri statute entirely omits the Vermont factor of whether the assertion was meritless and known to be meritless, instead indicating that a finding of bad faith may be appropriate on the (circular) basis of previous court rulings of bad faith enforcement. See Mo. Rev. Stat. § 416.652.2(5)-(6) (listing as factors indicating bad faith: (1) the patent holder "previously presented a demand letter claiming or asserting patent infringement of the same patent under substantially the same circumstances, and a court has entered a final judgment that the demand letter presented a bad faith assertion of patent infringement" and (2) the patent holder "attempted to enforce the claim of patent infringement in litigation, and a court found the claim to be brought in bad faith").

${ }^{94}$ Va. Code Ann. § 59.1-215.2.B.6.

${ }^{95}$ See infra Section IV.B.
} 
several other states, which lists specific acts of patent enforcement that are illegal.

In April 2014, Wisconsin became the third state, after Vermont and Oregon, to pass a statute regulating patent enforcement. ${ }^{96}$ Wisconsin's statute requires any "patent notification" 97 to contain several pieces of information, including:

- The number of each patent asserted. ${ }^{98}$

- Copies of those patents. ${ }^{99}$

- The name and address of the patent owner and all persons who have a right to enforce the patent. ${ }^{100}$

- An identification of each claim of each patent being asserted and of "the target's product, service, process, or technology to which that claim relates." 101

- "Factual allegations and an analysis setting forth in detail the person's theory of each claim identified ... and how that claim relates to the target's product, service, process, or technology."102

- "An identification of each pending or completed court or administrative proceeding ... concerning each patent” asserted. ${ }^{103}$

The Wisconsin statute can be violated in two ways. First, if a patent notification lacks any of the required information, the target may notify the sender that the notification is incomplete. ${ }^{104}$ If the sender does not provide the missing information within thirty days, the sender violates the statute. ${ }^{105}$ In addition, a patent notification violates the Wisconsin statute if it "contain[s] false, misleading, or deceptive information." 106

\footnotetext{
${ }^{96}$ Like the Vermont statute, Oregon's statute, which passed in March 2014, outlaws “bad faith” assertions of infringement. See 2014 Or. Laws 2545.

${ }^{97}$ The statute defines "patent notification" as "a letter, e-mail, or other written communication attempting in any manner to enforce or assert rights in connection with a patent or pending patent.” Wis. Stat. § 100.197(1)(a) (2014).

${ }_{98}$ Id. § 100.197(2)(a)(1).

${ }^{99}$ Id. § 100.197(2)(a)(2).

${ }^{100}$ Id. § 100.197(2)(a)(3).

${ }^{101}$ Id. § 100.197(2)(a)(4).

${ }^{102}$ Id. § 100.197(2)(a)(5).

${ }^{103}$ Id. § 100.197(2)(a)(6).

${ }^{104}$ Id. § 100.197(2)(c)(1).

105 Id. $\S 100.197(2)(c)(2)$

${ }^{106}$ Id. § 100.197(2)(b).
} 
As discussed in more detail below, the Wisconsin statute is vulnerable to a constitutional challenge because it condemns allegations of infringement that are merely false, not objectively baseless, and because it would condemn letters that omit some piece of required information but that contain otherwise accurate infringement allegations. ${ }^{107}$

A third and final model of legislation has been adopted in about a half-dozen states, beginning with Tennessee in May 2014. ${ }^{108}$ These statutes apply only to demand letters sent to end users, ${ }^{109}$ and most of the statutes apply only to letters sent by nonpracticing entities. ${ }^{110}$ The statutes outline four specific types of unlawful patent assertions. ${ }^{111}$ First, a patent demand letter violates the statute if it "falsely states that litigation has been filed" against the recipient. ${ }^{112}$ Second, a patent holder violates

${ }^{107}$ See infra Section IV.B. The Wisconsin statute provides remedies similar to those available under the Vermont statute. Specifically, the state attorney general may investigate violations and may sue to enjoin false, misleading, or deceptive patent notifications and to compel a sender to provide the information required by the statute. Wis. Stat. $\S 100.197(3)(a)(2)$. In addition, any person injured by a violation of the statute may pursue a civil action. Id. $\S 100.197(3)(b)$.

${ }^{108}$ Tenn. Code Ann. §§ 29-10-101 to -104 (2014). In addition to Tennessee, states adopting this model include Illinois, Kansas, Mississippi, Montana, Oklahoma, and Texas. See 815 Ill. Comp. Stat. 505/2RRR(a)-(b) (2015); 2015 Kan. Sess. Laws 920; H.B. 589, Reg. Sess. (Miss. 2015) (enacted); S.B. 39, 64th Leg. (Mont. 2015) (enacted); Okla. Stat. tit. 23, §§ 111-14 (2014); S.B. 1457, 84th Sess. (Tex. 2015) (enacted) (to be codified at Tex. Bus. \& Com. Code §§ 17.951-55).

${ }^{109}$ See 815 Ill. Comp. Stat. 505/2RRR(a)-(b) (stating that the statute applies only to communications sent to "a person who purchases, rents, leases, or otherwise obtains a product or service in the commercial market that is not for resale in the commercial market”); accord Okla. Stat. tit. 23, §§ 111(2), 112(A); Tenn. Code Ann. §§ 29-10-101(2), -102(a); Tex. S.B. 1457 at 1 (to be codified at Tex. Bus. \& Com. Code Ann. §§ 17.951, 17.952(a)); 2015 Kan. Sess. Laws 920; Miss. H.B. 589 §§ 1(b), 2(1); Mont. S.B. 39 §§ 1(2), 2(1).

${ }^{110}$ See Miss. H.B. $589 \S \S 1$ (b), 2(3)(a) (stating that the statute does not apply to communications sent by "[a]ny owner of a patent who is using the patent in connection with substantial research, development, production, manufacturing, processing or delivery of products or materials”); accord Okla. Stat. tit. 23, § 112(C)(1); Tenn. Code Ann. § 29-10-102(c)(1); 2015 Kan. Sess. Laws 921; Mont. S.B. 39 § 2(3)(a).

${ }^{111}$ Like the Vermont statute, the Kansas and Texas statutes outlaw "bad faith" assertions of patent infringement. Tex. S.B. 1457, at 1 (to be codified at Tex. Bus. \& Com. Code $\S 17.952(a)) ; 2015$ Kan. Sess. Laws 920. However, I have classified those statutes as falling into this third category because, rather than providing a variety of factors for courts to consider in determining bad faith, the Kansas and Texas statutes provide an exclusive list of scenarios in which patent enforcement is, under the statute, deemed to be in bad faith, see Tex. S.B. 1457, at 1-2 (to be codified at Tex. Bus. \& Com. Code § 17.952(b)); 2015 Kan. Sess. Laws 920-21, and that list resembles the specific prohibitions found in this third category of statutes.

112815 Ill. Comp. Stat. 505/2RRR(b)(2); Okla. Stat. tit. 23, § 112(A)(2); Tenn. Code Ann. $\S 29-10-102(a)(2) ;$ Tex. S.B. 1457, at 1 (to be codified at Tex. Bus. \& Com. Code 
the statute if the assertions in the demand letter "lack a reasonable basis in fact or law because" one of three things is true: (1) the person asserting the patent does not have the right to enforce it; (2) the demand letter is seeking compensation for a patent that has been held invalid or unenforceable; or (3) the demand letter seeks compensation for activities undertaken after the patent has expired. ${ }^{113}$ Third, a demand letter violates the statute if it does not identify the person asserting the patent, identify the patent itself, or contain "factual allegations concerning the specific areas in which the [recipient's] products, services, or technology infringe[] the patent." ${ }^{114}$ Finally, the statutes passed in Mississippi, Oklahoma, and Tennessee are violated if the demand letter "threatens litigation if compensation is not paid or the infringement issue is not otherwise resolved and there is a consistent pattern of such threats having been issued and no litigation having been filed." 115 Statutes passed in Illinois and Montana, by contrast, do not require a pattern of false threats, making it unlawful for any demand letter to "falsely threaten[]" litigation "if compensation is not paid or the infringement issue is not otherwise resolved." "116

The statutes also specify patent enforcement conduct that is not unlawful. Patent holders are explicitly allowed (1) to "advise others of [their] ownership" of the patent, (2) to "communicate to others that the patent is available for license or sale," (3) to "notify another of the infringement of the patent," and (4) to "seek compensation on account of

$\S$ 17.952(b)(1)); 2015 Kan. Sess. Laws 921; Miss. H.B. $589 \S 2(1)(b) ;$ Mont. S.B. 39 $\S 2(1)(a)$.

${ }^{113} 815$ Ill. Comp. Stat. 505/2RRR(b)(3); Okla. Stat. tit. 23 § 112(A)(3); Tenn. Code Ann. $\S 29-10-102$ (a)(3); Tex. S.B. 1457, at 1-2 (to be codified at Tex. Bus. \& Com. Code $\S 17.952(b)(2))$; Miss. H.B. 589 § 2(1)(c)(i)-(iii); Mont. S.B. 39 § 2(1)(b)(i)-(iii). The Kansas statute omits the first of these three grounds for finding a violation. 2015 Kan. Sess. Laws 921.

114815 Ill. Comp. Stat. 505/2RRR(b)(4)(B); Okla. Stat. tit. 23, § 112(A)(3)(d); Tenn. Code Ann. § 29-10-102(a)(3)(D); 2015 Kan. Sess. Laws 920; Miss. H.B. 589 § 2(1)(c)(iv); Mont. S.B. $39 \S 2(1)(i v)$. Rather than requiring factual allegations about how the recipient infringes, the Texas statute requires the letter to identify "at least one product, service, or technology" that infringes the patent, or "the activity" of the recipient that infringes the patent. Tex. S.B. 1457, at 2 (to be codified at Tex. Bus. \& Com. Code Ann. § 17.952(b)(3)(C)).

${ }^{115}$ Okla. Stat. tit. $23 \S 112(\mathrm{~A})(1)$; Tenn. Code Ann. § 29-10-102(a)(1); Miss. H.B. 589 $\S 2(1)(a)$.

116815 Ill. Comp. Stat. 505/2RRR(b)(1); accord Mont. S.B. 39 § 2(1)(a). Besides outlawing letters that falsely state that litigation has been filed, see supra note 112, the Kansas and Texas statutes do not address false threats of litigation. 2015 Kan. Sess. Laws 920-22; Tex. S.B. 1457, at 1-4 (to be codified at Tex. Bus. \& Com. Code $\S \S 17.951-55$ ). 
past or present infringement."117 At first glance, these exceptions appear to immunize the very conduct the statutes earlier deem unlawful. Practically all demand letters would seem to fall within the exceptions that allow patent holders to "notify" others "of the infringement" and to "seek compensation” for infringement. The Oklahoma statute appears to avoid this contradiction by stating that the exceptions apply only if the patent holder "is not acting in bad faith." ${ }^{118}$ But other states' statutes apply a "bad faith" requirement only to the exception that allows patent holders to "seek compensation" for infringement. ${ }^{119}$ And the Illinois statute omits the bad faith requirement altogether. ${ }^{120}$ Courts considering claims under these statutes will be forced to confront difficult questions about how these seemingly broad exceptions interact with the statute's explicit prohibitions. ${ }^{121}$

In sum, although the state statutes vary somewhat, they share common aims: ensuring that patent holders' demand letters provide accused infringers with specific information about the alleged infringement and

117815 Ill. Comp. Stat. 505/2RRR(c); Okla. Stat. tit. 23, § 112(B); Tenn. Code Ann. § 2910-102(b); Miss. H.B. $589 \S 2(2)$; Mont. S.B. $39 \S 2(2)$; accord Tex. S.B. 1457, at 3 (to be codified at Tex. Bus. \& Com. Code $\S 17.954(3)$ ). The Kansas statute takes a slightly different tack, listing several situations in which the statute is not violated, including when, among other things, the patent holder "has, as the owner of the patent and in good faith, sought compensation ... from the [recipient] by reason of infringement of its patent," the patent holder "has demonstrated good faith business practices in previous efforts to enforce the patent or a substantially similar patent," and the patent holder "has, as the owner of the patent and in good faith, communicated to any person that its patent is available for license or sale." 2015 Kan. Sess. Laws 921.

118 Okla. Stat. tit. 23, § 112(B).

${ }^{119}$ See Tenn. Code Ann. § 29-10-102(b)(4); Miss. H.B. $589 \S 2(2)(d) ;$ Mont. S.B. 39 $\S 2(2)(d)$.

${ }^{120} 815$ Ill. Comp. Stat. 505/2RRR(c). The Texas statute likewise does not apply a bad faith requirement to the portion of the statue describing the conduct that is not unlawful. Tex. S.B. 1457, at 3 (to be codified at Tex. Bus. \& Com. Code § 17.954(3)).

${ }^{121}$ Most of the statutes following this third model may, like the Vermont and Wisconsin statutes, be enforced by the state attorney general and through a civil action. See 815 Ill. Comp. Stat. 505/7, 505/10a; Tenn. Code Ann. §§ 29-10-103 to -104; Miss. H.B. 589 §§ 3-4; Mont. S.B. 39 § 3; see also Kan. Stat. Ann. §§ 50-632(a), 50-634(b), 50-636(a) (2014) (providing that the attorney general and private parties may file suit to enforce the state's consumer protection laws, of which Kansas's patent enforcement statute is a part); Okla. Stat. tit. 23, § 114 (not expressly creating a private right of action for violations of Oklahoma's patent enforcement statute, but stating that the court may award compensatory damages, attorneys' fees, and punitive damages "to a plaintiff who prevails in an action brought pursuant to this act”). But see Tex. S.B. 1457, at 3 (to be codified at Tex. Bus. \& Com. Code Ann. § 17.955) (“This subchapter does not create a private cause of action ....”). 
deterring patent holders from engaging in unfair or deceptive conduct in the hope of eliciting nuisance-value settlements.

\section{B. State Law Enforcement Actions}

Courts have not yet had the opportunity to interpret these new statutes, but attorneys general in several states have begun to use their powers under pre-existing consumer protection and deceptive trade practices laws to achieve the policy goals pursued by the statutes. State law enforcement efforts have thus far focused mainly on the notorious "scanner troll," MPHJ, and its lawyers. The Vermont attorney general, for instance, sued MPHJ in Vermont state court in May 2013, alleging that MPHJ's demand letters violated Vermont's general consumer protection statute. $^{122}$ (The suit was filed two weeks before Vermont's patent enforcement statute took effect.) As relief, the state sought an injunction requiring MPHJ to stop threatening Vermont businesses with patent infringement lawsuits, restitution to businesses harmed by MPHJ's actions, and civil penalties of up to $\$ 10,000$ for each violation. ${ }^{123}$ As of this writing, the case is pending in Vermont state court after MPHJ's unsuccessful attempt to remove the case to federal court. ${ }^{124}$

Around the same time Vermont sued MPHJ, the attorney general of Nebraska began an investigation into whether Farney Daniels, the law firm representing MPHJ and Activision TV, another nonpracticing entity, had violated Nebraska's consumer protection and deceptive trade practices statutes. ${ }^{125}$ (Nebraska has, to date, not passed a statute to specifically regulate patent enforcement.) In July 2013, the attorney general sent Farney Daniels a cease-and-desist order that prohibited the firm from initiating new patent enforcement efforts in Nebraska. ${ }^{126}$ As discussed in more detail below, Activision and MPHJ obtained an injunc-

${ }^{122}$ See Consumer Protection Complaint at 1-8, Vermont v. MPHJ Tech. Invs., LLC, No. 282-5-13wncv (Vt. Super. Ct. May 8, 2013), available at http://www.atg.state.vt.us/assets/ files/Vermont\%20v\%20MPHJ\%20Technologies\%20Complaint.pdf.

123 See id. at 10.

${ }^{124}$ See Vermont v. MPHJ Tech. Invs., LLC, No. 2:13-cv-170, 2014 WL 1494009, at *1 (D. Vt. Apr. 15, 2014).

${ }^{125}$ See Richard Piersol, Bruning, Nebraska Companies Enveloped in Patent Litigation, Lincoln J. Star, Aug. 24, 2013, http://journalstar.com/business/local/bruning-nebraska-companiesenveloped-in-patent-litigation/article_aac06dd8-504f-5086-9878-3036c7c0fbc8.html.

${ }^{126}$ Letter from Jon Bruning, Attorney Gen. of Neb., to M. Brett Johnson, Partner, Farney Daniels LLP (July 18, 2013), available at http://www.essentialpatentblog.com/wpcontent/uploads/sites/234/2014/01/2013-07-18-AG-Cease-and-Desist-Order.pdf. 
tion prohibiting enforcement of that order, with the district court holding that, under Federal Circuit law, the order was "preempted by federal [patent] law." 127

In addition, the attorneys general of two states, New York and Minnesota, have negotiated agreements with MPHJ to curb its enforcement activity. An agreement between MPHJ and the attorney general of Minnesota requires the company, before sending any demand letters to Minnesota businesses, to give the attorney general's office sixty days' notice and to obtain its consent. ${ }^{128}$ Similarly, an "Assurance of Discontinuance" between MPHJ and the attorney general of New York prohibits MPHJ from asserting its patents through shell subsidiaries without disclosing the subsidiaries' relationship to MPHJ and also imposes detailed guidelines for future assertions of infringement. ${ }^{129}$

In sum, patent enforcement campaigns targeted at end users have spurred state legislatures and state law enforcement officials to take an increased interest in patent law. Under Federal Circuit law, however, this federalism revolution may be unconstitutional.

\section{PREEMPTION AND PETITIONING IMMUNiTy}

The constitutional barrier that immediately comes to mind, given the federal nature of substantive patent law, is preemption under the Supremacy Clause. Some states that have passed statutes regulating patent enforcement appear to be aware of preemption concerns. The preamble to the Vermont statute, for instance, states that the legislature "recognizes that Vermont is preempted from passing any law that conflicts with federal patent law."130 And the Alabama statute instructs that the act "shall be interpreted consistently with any federal law or regulations

\footnotetext{
${ }^{127}$ Activision TV, Inc. v. Bruning, No. 8:13-cv-215, slip. op. at 5, 10 (D. Neb. Sept. 2, 2014) (citing Globetrotter Software, Inc. v. Elan Computer Grp., 362 F.3d 1367 (Fed. Cir. 2004)); see also infra Section IV.C (discussing the Activision case in more detail).

${ }^{128}$ Julie Samuels, Minnesota: Patent Trolls Are Not Welcome Here, Elec. Frontier Found. (Aug. 21, 2013), https://www.eff.org/deeplinks/2013/08/minnesota-patent-trolls-are-not-welcomehere.

${ }^{129}$ Investigation by Eric T. Schneiderman, Attorney Gen. of the State of New York, MPHJ Technology Investments, LLC, Assurance No. 14-015, at 1, 12-19 (Jan. 13, 2014). For example, MPHJ agreed that it will not assert patents against businesses or individuals in New York unless it makes "reasonable efforts to identify and evaluate a specific accused product, system, or method that the [accused infringer] makes, uses, offers to sell, or sells that [MPHJ] believes in good faith actually infringes the [a]sserted patent.” Id. at 12.

${ }^{130}$ Vt. Stat. Ann. tit. 9, § 4195(a)(3) (2014).
} 
governing patents or patent infringement.”131 Under Supreme Court precedent interpreting the Supremacy Clause, however, these new statutes likely avoid preemption. Yet the Federal Circuit has treated those Supreme Court decisions-including decisions that deal specifically with the preemptive scope of the federal Patent Act-as mostly irrelevant when assessing the power of the states to regulate patent enforcement. Instead, the Federal Circuit has relied on the Noerr-Pennington doctrine to hold that, because of the Petition Clause of the First Amendment, states may outlaw assertions of infringement only if the patent holder made the allegations with knowledge that they were objectively baseless.

\section{A. Federal Preemption}

Federal preemption doctrine permits Congress, by virtue of the Supremacy Clause, to displace state laws when exercising its legislative powers under Article I. The Supreme Court has decided several cases exploring the extent to which the federal Patent Act preempts state laws that grant patent-like intellectual property rights. If courts were to apply the reasoning of those decisions to state laws regulating patent enforcement, it seems unlikely those state laws would be preempted.

\section{Preemption Generally}

Preemption doctrine is grounded in the Supremacy Clause, which provides in relevant part: "This Constitution, and the Laws of the United States which shall be made in Pursuance thereof ... shall be the supreme Law of the Land; and the Judges in every State shall be bound thereby, any Thing in the Constitution or Laws of any State to the Contrary notwithstanding." 132 Preemption can be either express or implied.

The doctrine of express preemption recognizes that Congress may withdraw specific powers from the states by enacting a statute that says so. ${ }^{133}$ Express preemption doctrine is largely irrelevant in patent matters.

\footnotetext{
${ }^{131}$ Ala. Code § 35-4-405(b) (LexisNexis 2014).

${ }^{132}$ U.S. Const. art. VI, $\S 2$. For a challenge to the conventional view that preemption doctrine flows from the Supremacy Clause, see Stephen A. Gardbaum, The Nature of Preemption, 79 Cornell L. Rev. 767, 769 (1994). For an exploration of the preemptive effect of the IP Clause, U.S. Const. art. I, § 8, cl. 8, which empowers Congress to create the patent and copyright laws, see Fromer, supra note 52, at 265, 276-81.

${ }^{133}$ See Arizona v. United States, 132 S. Ct. 2492, 2500-01 (2012).
} 
As the Federal Circuit has noted, the federal Patent Act "plainly does not provide for" express preemption. ${ }^{134}$

Patent preemption disputes therefore focus on implied preemption. One type of implied preemption potentially relevant to patent matters, given that substantive patent law is entirely federal, is field preemption. Field preemption arises when there is a framework of regulation "so pervasive ... that Congress left no room for the States to supplement it" or when there is a "federal interest ... so dominant that the federal system will be assumed to preclude enforcement of state laws on the same subject." 135 Another variety of implied preemption that is potentially relevant to the new state patent enforcement statutes is conflict preemption. Conflict preemption occurs when, among other things, state law "stands as an obstacle to the accomplishment and execution of the full purposes and objectives of Congress." ${ }^{136}$ As discussed in more detail below, one might suggest that the new state laws conflict with patent holders' obligation under the federal Patent Act to notify alleged infringers of their infringement. $^{137}$

Although commentators have claimed that modern preemption doctrine is, among other things, a "muddle," 138 the Supreme Court has been quite clear that "the purpose of Congress is the ultimate touchstone in every pre-emption case." 139 Of course, the difficulty in implied preemption disputes is that the statute itself, by definition, says nothing explicit about Congress's purpose to preempt or merely to supplement state law. Accordingly, Thomas Merrill has reduced the implied preemption analysis to three basic inquiries: determining the requirements of the federal statute or regulation at issue, determining what the relevant state law requires, and then asking whether any tension between the state law and federal law "is sufficiently severe to warrant the displacement of state law in light of all relevant factors that bear on this decision." ${ }^{140}$ Rather than asking a hollow question about Congress's nonexistent or indeterminate intent, this framework recognizes that implied preemption analy-

\footnotetext{
${ }^{134}$ Hunter Douglas, Inc. v. Harmonic Design, Inc., 153 F.3d 1318, 1332 (Fed. Cir. 1998).

${ }^{135}$ Rice v. Santa Fe Elevator Corp., 331 U.S. 218, 230 (1947).

${ }^{136}$ Hines v. Davidowitz, 312 U.S. 52, 67 (1941).

${ }^{137}$ See 35 U.S.C. § 287(b)(5) (2012); infra notes 162-64 and accompanying text.

${ }^{138}$ Caleb Nelson, Preemption, 86 Va. L. Rev. 225, 232-33 (2000) (citing additional criticism).

${ }^{139}$ Medtronic, Inc. v. Lohr, 518 U.S. 470, 485 (1996) (quoting Retail Clerks Int'l Ass'n, Local 1625 v. Schermerhorn, 375 U.S. 96, 103 (1963)) (internal quotation marks omitted).

${ }^{140}$ Thomas W. Merrill, Preemption and Institutional Choice, 102 Nw. U. L. Rev. 727, 743 (2008).
} 
sis is, at bottom, "a multifaceted, high-stakes discretionary policy judgment." 141

\section{The Supreme Court on Patent Preemption}

The Supreme Court's preemption decisions dealing specifically with patent matters are consistent with the implied preemption framework deployed in other substantive areas. That is, it looks nothing like the Noerr-based "preemption" test the Federal Circuit has applied to state law claims challenging a patent holder's enforcement behavior. To be sure, none of these Supreme Court cases involved state laws regulating patent enforcement. But the structure of the Court's analysisexamining the policies behind the patent-related state law and weighing it against the policies embodied in federal patent law-is plainly relevant to the question of whether federal patent law preempts state laws regulating patent assertions.

The Supreme Court's patent preemption doctrine traces its roots to a pair of decisions issued in 1964. In those decisions, the Court held preempted a state unfair competition law that the lower courts had construed to prohibit the copying of unpatented lamps and light fixtures that had been sold to the public. ${ }^{142}$ The Court reasoned that the state law "clashed with" federal law because the designs of the widely available lamps and fixtures were, under the Patent Act, in the public domain. ${ }^{143}$

A decade later, Kewanee Oil Co. v. Bicron Corp. presented the question of whether Ohio's trade secrets law was preempted by federal patent law. ${ }^{144}$ Elaborating on its conflict preemption analysis, the Court noted that " $[t]$ o determine whether the Ohio law 'clashes' with the federal law it is helpful to examine the objectives of both the patent and trade secret laws." 145 The Court identified three purposes of the federal

\footnotetext{
${ }^{141}$ Id. at 744; see also Richard A. Epstein \& Michael S. Greve, Introduction: Preemption in Context, in Federal Preemption: States’ Powers, National Interests 1, 2 (Richard A. Epstein \& Michael S. Greve eds., 2007) (“[I]t has come to be widely acknowledged ... that preemption questions cannot be reduced to the judicial exegesis of (often ambiguous) federal statutes. While statutory interpretation is a large part of the preemption picture, preemption doctrine is also, and centrally, a question of institutional design and constitutional understanding.”).

${ }^{142}$ Compco Corp. v. Day-Brite Lighting, Inc., 376 U.S. 234, 237-38 (1964); Sears, Roebuck \& Co. v. Stiffel Co., 376 U.S. 225, 231-32 (1964).

${ }^{143}$ Compco, 376 U.S. at 237-38; Sears, 376 U.S. at 231-33.

144416 U.S. 470, 472 (1974).

${ }^{145}$ Id. at 480 (quoting Sears, 376 U.S. at 231).
} 
patent laws: to provide an incentive for inventors; to induce disclosure of inventions; and, through the requirements of patent validity such as novelty and nonobviousness, to ensure that ideas in the public domain stay there. ${ }^{146}$ As for the purposes of state trade secrets law, the Court noted two: maintaining standards of commercial ethics and encouraging invention. ${ }^{147}$

The Court held that Ohio's trade secrets law was not an obstacle to achieving the purposes of federal patent law. The Court noted that the federal policy of encouraging invention is not disturbed by the existence of an additional incentive for invention and that the federal policy of protecting the public domain was not disturbed by trade secrets law because trade secrets, by definition, have not been disclosed to the public. ${ }^{148}$ The Court conceded that state trade secret protection for inventions that are also patentable would be an obstacle to the federal policy of encouraging disclosure. ${ }^{149}$ The Court characterized this obstacle as minor, however, because in its view few inventors would choose the "far weaker" protection of trade secrets law, ${ }^{150}$ and because many inventions are made independently by multiple people close in time and those later inventors may disclose the invention. ${ }^{151}$

The Court in Kewanee also highlighted the states' interest in the continued existence of their trade secrets laws. For example, the Court noted the states' interest in regulating the ethics of the marketplace, writing: "Nothing in the patent law requires that States refrain from action to prevent industrial espionage. . . . A most fundamental human right, that of privacy, is threatened when industrial espionage is condoned or is made profitable; the state interest in denying profit to such illegal ventures is unchallengeable." 152 The Court also emphasized the long history of state laws protecting trade secrets, noting that "[t]rade secret law and

\footnotetext{
${ }^{146}$ Id. at $480-81$.

${ }^{147}$ Id. at 481 .

148 Id. at 484 .

149 Id. at 489.

${ }^{150}$ For instance, trade secrets law, unlike patent law, does not prohibit reverse engineering. See Mark A. Lemley, The Surprising Virtues of Treating Trade Secrets as IP Rights, 61 Stan. L. Rev. 311, 330 (2008).

${ }^{151}$ Kewanee, 416 U.S. at 489-91. The Court's assumption that few inventors would choose trade secret protection over patent protection has been widely criticized. See, e.g., Richard H. Stern, A Reexamination of Preemption of State Trade Secret Law After Kewanee, 42 Geo. Wash. L. Rev. 927, 946 (1974).

${ }^{152}$ Kewanee, 416 U.S. at 487.
} 
patent law have co-existed in this country for over one hundred years.” 153

The Court's most recent word on patent preemption suggested that state interests continue to be relevant to the analysis. Bonito Boats, Inc. v. Thunder Craft Boats, Inc. presented the question of whether federal patent law preempted a Florida statute that prohibited duplicating boat hulls that were not patentable under federal law. ${ }^{154}$ Explaining its refusal to find preemption in Kewanee, the Court in Bonito Boats emphasized that "certain aspects of trade secret law operated to protect noneconomic interests outside the sphere of congressional concern in the patent laws," such as preventing economic espionage. ${ }^{155}$ The Court also identified what is arguably a fourth purpose of federal patent law, noting that "[o]ne of the fundamental purposes behind the Patent and Copyright Clauses of the Constitution was to promote national uniformity in the realm of intellectual property." 156 "This purpose," the Court noted, was "frustrated by the Florida scheme, which render[ed] the status of the design and utilitarian 'ideas' embodied in . . . boat hulls . . uncertain.” ${ }^{157}$

\section{Preemption of State Patent Enforcement Statutes Under the Supremacy Clause}

Under the Supreme Court's preemption case law, there is a strong argument that state laws regulating patent enforcement, such as the new statutes, are not preempted. To begin with, it is difficult to see how any of the three objectives of federal patent law identified in Kewanee would be compromised by state law claims challenging bad faith or deceptive enforcement conduct. As the Federal Circuit itself noted in ruling that a state law tort claim against a patent holder was not preempted under Kewanee, "it seems most improbable that an inventor would choose to forfeit the benefits of patent protection because of fear of the risk of being found tortiously liable" for its enforcement conduct. ${ }^{158}$ Also, similar to the long history of state trade secrets law discussed in Kewanee, ${ }^{159}$ the states have traditionally played a role in regulating abusive and anticom-

\footnotetext{
153 Id. at 493.

${ }^{154} 489$ U.S. 141, 144 (1989).

155 Id. at 155.

${ }^{156}$ Id. at 162.

${ }^{157}$ Id.

${ }^{158}$ Dow Chem. Co. v. Exxon Corp., 139 F.3d 1470, 1475 (Fed. Cir. 1998).

${ }^{159} 416$ U.S. at 493.
} 
petitive assertions of legal rights through common law torts such as wrongful use of civil proceedings, abuse of process, tortious interference, and business disparagement. Those bodies of law serve purposes much different from the innovation-promoting purpose of the federal patent laws.

State-by-state regulation of patent enforcement does threaten to impede national uniformity, which was one of the Court's reasons for finding preemption in Bonito Boats. Yet it is not as if the fifty different states take fifty different approaches to unfair competition law, deceptive trade practices law, or business torts. Many of the new state statutes are also similar, condemning "bad faith" assertions of patent infringement. ${ }^{160}$ In addition, the uniformity with which the Supreme Court was concerned in Bonito Boats was uniformity in the scope of intellectual property rights. When the Court has been confronted with bodies of state law, such as contract law, that govern intellectual property rights whose scope has already been determined by federal law, the Court has allowed state law room to operate. ${ }^{161}$

Of course, none of the Supreme Court's patent preemption cases involve state laws regulating patent enforcement. Thus, one might reasonably look beyond Kewanee and Bonito Boats and suggest that state laws regulating assertions of patent infringement conflict with the provision of the Patent Act requiring patent holders, as a prerequisite to recovering damages for infringement, to provide accused infringers with notice of their infringement. ${ }^{162}$ The Federal Circuit has emphasized that federal law protects the right of a patent holder to provide notice to an accused infringer so that the accused infringer "can determine whether to cease its allegedly infringing activities, negotiate a license if one is offered, or decide to run the risk of liability and/or the imposition of an injunction." ${ }^{163}$ As the Federal Circuit has also recognized, however, the patent holder loses its protection if it sends those notifications "in bad faith." 164 Thus, a state statute that outlawed sending any type of notice would be preempted for conflict with federal law. But state laws that merely out-

\footnotetext{
${ }^{160}$ See supra Section I.A.

${ }^{161}$ See, e.g., Aronson v. Quick Point Pencil Co., 440 U.S. 257, 262 (1979) (holding that federal patent law did not preempt a state law breach of contract claim seeking royalties for sales of an invention that was the subject of an unsuccessful patent application).

${ }^{162}$ See 35 U.S.C. § 287(a) (2012).

${ }^{163}$ Va. Panel Corp. v. MAC Panel Co., 133 F.3d 860, 869 (Fed. Cir. 1997).

${ }^{164}$ E.g., Zenith Elecs. Corp. v. Exzec, Inc., 182 F.3d 1340, 1343 (Fed. Cir. 1999).
} 
law the smaller class of patent notices sent in bad faith do not present the same danger of interference with the federal scheme of notification.

Drawing on principles of field preemption, one might suggest that state anti-troll statutes are preempted because they touch on a distinctly federal matter: the enforcement of patents. The Supreme Court has invoked a similar rationale to preempt, for example, state law tort claims based on fraud before the Food and Drug Administration ${ }^{165}$ and an Arizona law that attempted to regulate immigration. ${ }^{166}$ The Constitution certainly makes patents a matter of federal concern, ${ }^{167}$ and Congress has given the federal courts exclusive jurisdiction over suits arising under patent law. ${ }^{168}$ As noted, however, many different bodies of state law govern patent rights created by federal law and are not preempted, including contract law, family law, and probate law. ${ }^{169}$ In fact, the new statutes regulating patent enforcement are not the only statutes state legislatures have passed to specifically govern federal patent rights. Numerous states have statutes that regulate the ownership of patented inventions developed by employees. ${ }^{170}$ None of those statutes, to my knowledge, have been struck down on preemption grounds. Moreover, the field preemption argument is weakened by the fact that the federal Patent Act simply does not address the issue of unfair or deceptive patent enforcement-it neither condemns nor immunizes it. This distinguishes the new state patent enforcement statutes from state laws the Supreme Court has found preempted for touching on distinctly federal matters. The federal food and drug laws, for instance, contain "various provisions aimed at detecting, deterring, and punishing false statements made during ... [the] approval processes," ${ }^{171}$ and the federal immigration laws address many of the issues that the Arizona statute sought to regulate, such as registration and employment requirements. ${ }^{172}$

\footnotetext{
${ }^{165}$ See Buckman Co. v. Plaintiffs’ Legal Comm., 531 U.S. 341, 347-48 (2001).

${ }^{166}$ See Arizona v. United States, 132 S. Ct. 2492, 2501 (2012).

${ }^{167}$ See U.S. Const. art. I, § 8, cl. 8 ("The Congress shall have Power ... [t]o promote the Progress of Science and useful Arts, by securing for limited Times to Authors and Inventors the exclusive Right to their respective Writings and Discoveries.”).

${ }^{168}$ See 28 U.S.C. § 1338(a) (2012).

${ }^{169}$ See supra Part I.

${ }^{170}$ See, e.g., Cal. Lab. Code $\S 2870$ (West 2014); Employee Patent Act, 765 Ill. Comp. Stat. Ann. 1060/2 (2014); Nev. Rev. Stat. Ann. § 600.500 (West 2014); see also Robert P. Merges, Peter S. Menell \& Mark A. Lemley, Intellectual Property in the New Technological Age 87 (6th ed. 2012) (collecting statutes).

${ }_{171}$ Buckman Co. v. Plaintiffs’ Legal Comm., 531 U.S. 341, 349 (2001).

${ }^{172}$ Arizona v. United States, 132 S. Ct. 2492, 2501-05 (2012).
} 
Also, federal courts may be less willing to find preemption as state patent enforcement laws continue to proliferate and state law enforcement officials take an active regulatory role. ${ }^{173}$ Indeed, the Supreme Court recently ruled that the federal courts' exclusive patent jurisdiction does not extend to state law claims alleging legal malpractice in the handling of a patent case, ${ }^{174}$ opening the door for state courts to occasionally opine on the substance of federal patent law. And even the Federal Circuit, which has generally shielded patent holders from state law liability for their enforcement activity, has refused to find field preemption of state law tort and unfair competition claims against patent holders. ${ }^{175}$

That said, to the extent that the new state laws essentially create a new tort claim, one might expect a conservative Supreme Court to eagerly find that tort claim preempted. ${ }^{176}$ Then again, as Ernest Young as observed, "preemption cases implicate a number of cross-cutting ideological and methodological conflicts on the Court," so it can be hazardous to predict the outcome of a preemption case based solely on politics. ${ }^{177}$ In the end, given the unpredictability of preemption analysis, ${ }^{178}$ it is impossible to forecast with certainty whether the Supreme Court would find preempted state statutes regulating patent enforcement. My point here, though, is simple: Under a traditional, Supremacy Clause-based preemption analysis - unlike under the Federal Circuit's First Amendmentbased "preemption" rule - the states arguably have the authority to regulate patent enforcement.

\section{B. Petitioning Immunity}

Before exploring the Federal Circuit case law that renders the states practically powerless to regulate patent enforcement, it is helpful to cover some background on how federal law protects from civil liability per-

\footnotetext{
${ }^{173}$ See Gillian E. Metzger, Federalism and Federal Agency Reform, 111 Colum. L. Rev. 1, 18 (2011) (noting that several recent Supreme Court preemption decisions "reflect judicial unease over increasing federal displacement of state law and state regulatory authority").

${ }^{174}$ Gunn v. Minton, 133 S. Ct. 1059, 1068 (2013).

${ }^{175}$ See, e.g., Hunter Douglas, Inc. v. Harmonic Design, Inc., 153 F.3d 1318, 1334 (Fed. Cir. 1998).

${ }^{176}$ See Metzger, supra note 173, at 4.

${ }^{177}$ Ernest A. Young, “The Ordinary Diet of the Law”: The Presumption Against Preemption in the Roberts Court, 2011 Sup. Ct. Rev. 253, 304, 342.

${ }^{178}$ See David S. Rubenstein, Delegating Supremacy?, 65 Vand. L. Rev. 1125, 1139 (2012) (noting that 'the preemption calculus yields a 'muddled,' 'haphazard,' and unpredictable jurisprudential landscape”).
} 
sons who petition the government through means such as filing lawsuits. Like preemption, these doctrines of petitioning immunity have constitutional dimensions. Specifically, the First Amendment provides that "Congress shall make no law respecting an establishment of religion, or prohibiting the free exercise thereof; or abridging the freedom of speech, or of the press; or the right of the people peaceably to assemble, and to petition the Government for a redress of grievances." ${ }^{179}$ The Supreme Court has grappled with the Petition Clause in two lines of cases.

First, the Supreme Court in several cases has considered claims by plaintiffs that a defendant's petition to the government violated the antitrust laws. This line of cases begins with Eastern Railroad Presidents Conference v. Noerr Motor Freight, Inc., which involved a publicity campaign by the railroad industry "designed to foster the adoption and retention of laws and law enforcement practices destructive of the trucking business." ${ }^{280}$ The Court held that the railroads were immune from an antitrust suit brought by truck operators "insofar as [the railroads'] activities comprised mere solicitation of governmental action with respect to the passage and enforcement of laws." 181

The Court based this immunity on its interpretation of the federal antitrust statute, the Sherman Act, noting that agreements among firms to seek favorable legislation or executive action "bear very little if any resemblance to the combinations normally held violative of the Sherman Act," which usually involve agreements to "give up . . . trade freedom" or to "take away the trade freedom of others" through acts of pricefixing or market division. ${ }^{182}$ The Court continued: "To hold ... that the people cannot freely inform the government of their wishes would impute to the Sherman Act a purpose to regulate, not business activity, but political activity, a purpose which would have no basis whatever in the legislative history of that Act." 183 The Court's interpretation of the Sherman Act was influenced by the First Amendment, as the Court noted that construing the Sherman Act to regulate the railroads' publicity campaign "would raise important constitutional questions." 184 "The right

\footnotetext{
${ }^{179}$ U.S. Const. amend. I (emphasis added). On the history of the right to petition, which can be traced back to Magna Carta and earlier, see Gary Lawson \& Guy Seidman, Downsizing the Right to Petition, 93 Nw. U. L. Rev. 739, 743-56 (1999).

180365 U.S. 127, 129 (1961).

${ }^{181} \mathrm{Id}$. at 138.

182 Id. at 136.

183 Id. at 137.

${ }^{184}$ Id. at 138.
} 
of petition," the Court explained, "is one of the freedoms protected by the Bill of Rights, and we cannot ... lightly impute to Congress an intent to invade these freedoms." 185

The Court in Noerr also made clear that immunity from antitrust liability based on petitioning activity is not unlimited. In articulating what came to be known as the "sham" exception to the Noerr doctrine, the Court noted that "[t]here may be situations in which a publicity campaign, ostensibly directed toward influencing governmental action, is a mere sham to cover what is actually nothing more than an attempt to interfere directly with the business relationship of a competitor." ${ }^{186}$ In those situations, the Court explained, "the application of the Sherman Act would be justified." 187

Although the Noerr decision itself immunized from antitrust liability the act of lobbying the legislature and the executive, the Court later extended Noerr immunity to the act of pursuing litigation. ${ }^{188}$ In Professional Real Estate Investors, Inc. v. Columbia Pictures Industries, Inc., ${ }^{189}$ the Court elaborated on the showing required to establish the sham exception, adopting the two-part test that would heavily influence the Federal Circuit's preemption rule. In Professional Real Estate Investors, the plaintiff, a hotel operator, alleged that the defendant movie studios had violated the antitrust laws by bringing a copyright infringement suit when the studios "did not honestly believe that the infringement claim was meritorious." " 190 The Court rejected the antitrust claim because it was based solely on the defendants' subjective intent. ${ }^{191}$ In so doing, the Court articulated the requirements for stripping a defendant of antitrust immunity in a "two-part definition of 'sham' litigation":

First, the lawsuit must be objectively baseless in the sense that no reasonable litigant could realistically expect success on the merits. If an objective litigant could conclude that the suit is reasonably calculated to elicit a favorable outcome, the suit is immunized under Noerr, and critique of this expansion of Noerr, see David McGowan \& Mark A. Lemley, Antitrust Immunity: State Action and Federalism, Petitioning and the First Amendment, 17 Harv. J.L. \& Pub. Pol’y 293, 399 (1994).

189508 U.S. 49 (1993).

190 Id. at 54 .

${ }^{191}$ Id. at 57.
} 
an antitrust claim premised on the sham exception must fail. Only if challenged litigation is objectively meritless may a court examine the litigant's subjective motivation. Under this second part of our definition of sham, the court should focus on whether the baseless lawsuit conceals an attempt to interfere directly with the business relationships of a competitor, through the use of the governmental process-as opposed to the outcome of that process-as an anticompetitive weapon. ${ }^{192}$

Although Noerr immunity is now firmly embedded in the Supreme Court's antitrust case law, the Court has never held that defendants can invoke Noerr as protection against claims not sounding in antitrust. ${ }^{193}$ To that end, scholars have vigorously debated whether the immunity doctrine that stems from Noerr is based on the First Amendment, in which case it would provide immunity from all types of civil claims, not just antitrust claims, or on the Court's interpretation of the Sherman Act, in which case Noerr would provide immunity only from antitrust claims. ${ }^{194}$ Although the matter remains unsettled, some suggestion that Noerr has limited relevance to patent matters can be found in the Supreme Court's recent decision in Octane Fitness, LLC v. ICON Health \& Fitness, Inc. ${ }^{195}$ In that case, the Court overturned Federal Circuit case law that required a prevailing party seeking attorneys' fees in a patent

\footnotetext{
${ }^{192}$ Id. at 60-61 (citations, footnote, and internal quotation marks omitted).

193 The Supreme Court has, to be sure, drawn on Noerr in other areas, particularly in articulating the ability of the National Labor Relations Board to condemn retaliatory lawsuits filed by employers against their employees. See, e.g., BE\&K Const. Co. v. NLRB, 536 U.S. 516, 525, 536 (2002) (citing Prof'l Real Estate Investors, 508 U.S. at 69; Cal. Motor Transp., 404 U.S. at 511; E. R.R. Presidents Conference v. Noerr Motor Freight, Inc., 365 U.S. 127, 144 (1961)) (holding that the National Labor Relations Act ("NLRA") does not permit the Board to impose liability on an employer for its "reasonably based but unsuccessful suits filed with a retaliatory purpose”); Bill Johnson's Rests. v. NLRB, 461 U.S. 731, 744 (1983) (citing Cal. Motor Transp., 404 U.S. at 510) (holding that, under the NLRA, the Board may enjoin an employer's "baseless lawsuit [filed] with the intent of retaliating against an employee”).

${ }^{194}$ See Einer Elhague, Making Sense of Antitrust Petitioning Immunity, 80 Calif. L. Rev. 1177, 1194 \& n.99 (1992) (collecting commentary). Elhague expressly avoids engaging questions about the basis of Noerr immunity, instead urging a "functional process" approach to antitrust immunity that assesses whether the decision maker who imposed the restraint had "an objective financial interest in the restraint's anticompetitive consequences.” Id. at 1180, 1194.

195134 S. Ct. 1749 (2014).
} 
case to satisfy Noerr by showing that its opponent pursued an objectively baseless case in subjective bad faith. ${ }^{196}$

Nevertheless, lower courts have widely concluded that Noerr's First Amendment aspects require the doctrine to be applied to all types of civil claims seeking to impose liability for litigation conduct, not just to antitrust claims. ${ }^{197}$ For example, courts have applied the doctrine to claims of tortious interference, abuse of process, defamation, intentional infliction of emotional distress, and even civil rights claims. ${ }^{198}$ In addition, many lower courts have extended Noerr to immunize not only the act of pursuing litigation in court but also statements made in pre-litigation communications. ${ }^{199}$ As discussed in more detail below, the Federal Circuit has embraced all of these expansions of Noerr immunity to broadly protect patent holders from any type of civil liability based on their enforcement conduct, whether or not that conduct relates to a pending lawsuit. $^{200}$

In a second line of cases involving the Petition Clause, however, the Supreme Court has provided some guidance about the scope of the right to petition when the antitrust laws are not involved, casting doubt on the lower courts' unflinching expansion of Noerr immunity to all types of

${ }^{196}$ Id. at 1757 . Even if Noerr is based entirely on the First Amendment, as some have argued, see, e.g., Daniel R. Fischel, Antitrust Liability for Attempts to Influence Government Action: The Basis and Limits of the Noerr-Pennington Doctrine, 45 U. Chi. L. Rev. 80, 100 (1977); McGowan \& Lemley, supra note 188, at 301, the First Amendment does not, in my view, protect deceptive or false statements made in demand letters sent between private parties. See infra Section V.A.

${ }^{197}$ See, e.g., IGEN Int'l v. Roche Diagnostics, 335 F.3d 303, 310 (4th Cir. 2003) ("[A]lthough originally developed in the antitrust context, the doctrine has now universally been applied to business torts.”).

${ }^{198}$ See Carol Rice Andrews, Motive Restrictions on Court Access: A First Amendment Challenge, 61 Ohio St. L.J. 665, 678 n.59 (2000) (collecting cases); Aaron R. Gary, First Amendment Petition Clause Immunity from Tort Suits: In Search of a Consistent Doctrinal Framework, 33 Idaho L. Rev. 67, 95-97 (1996) (same). Noerr has also successfully been invoked by defendants to strategic lawsuits against public participation ("SLAPPs") lawsuits, often claims for defamation or tortious interference, that are filed to intimidate defendants from exercising their petitioning and free speech rights. See, e.g., Protect Our Mountain Env't, Inc. v. Dist. Court, 677 P.2d 1361, 1369 (Colo. 1984) (holding that, to avoid dismissal on First Amendment grounds, the plaintiff in an alleged SLAPP must show, among other things, that the defendant's actions were "devoid of reasonable factual support[] or ... lacked any cognizable basis in law" and were made for "the primary purpose of ... harass[ing] the plaintiff or ... effectuat[ing] some other improper objective”).

${ }^{199}$ See 1 Phillip E. Areeda \& Herbert Hovenkamp, Antitrust Law 9 205f, at 302-03 (4th ed. 2013) (citing cases).

${ }^{200}$ See infra Part III. 
civil claims. Most notable among those decisions is McDonald $v$. Smith. ${ }^{201}$ In that case, the defendant wrote two letters to the President alleging that the plaintiff, who was being considered for a position as a U.S. Attorney, had engaged in blackmail, extortion, and civil rights violations. ${ }^{202}$ The plaintiff did not get the position and sued the defendant for libel. ${ }^{203}$ The Court rejected the defendant's argument that the Petition Clause granted him absolute immunity from the libel claim. ${ }^{204}$ The Court noted that to accept that argument "would elevate the Petition Clause to special First Amendment status" when, in fact, it "was inspired by the same ideals of liberty and democracy that gave us the freedoms to speak, publish, and assemble." ${ }^{205}$ Accordingly, the Court reasoned, "there is no sound basis for granting greater constitutional protection to statements made in a petition to the President than other First Amendment expressions.” ${ }^{206}$ Because the relevant state law required the plaintiff to prove that the defendant acted with malice, which was consistent with the Court's precedent on the right to free speech, the Court held that the right to petition did not preclude the libel suit. ${ }^{207}$

The Supreme Court's decision in McDonald casts doubt on the lower courts' grant of Noerr immunity to defendants faced with non-antitrust claims. Noerr, recall, was arguably based on an interpretation of the Sherman Act in light of the First Amendment right to petition. ${ }^{208}$ If the Sherman Act is removed from the picture, the defendant's sole protection is the Petition Clause, and McDonald appears to be the more relevant case. ${ }^{209}$ In McDonald, the Court suggested that the Petition Clause allows state tort law room to operate, so long as that state law does not

\footnotetext{
201472 U.S. 479 (1985).

${ }^{202}$ Id. at $480-81$.

203 Id.

${ }^{204}$ Id. at 485.

${ }^{205}$ Id. For a critique of the Court's "unwillingness to give independent meaning and effect to the Petition Clause," see Ronald J. Krotoszynski, Jr., Reclaiming the Petition Clause 15762 (2012).

${ }^{206}$ McDonald, 472 U.S. at 485.

${ }^{207}$ Id. (citing N.Y. Times Co. v. Sullivan, 376 U.S. 254 (1964))

${ }^{208}$ See supra text accompanying notes 182-85; see also Nat'l Org. for Women, Inc. v. Scheidler, 510 U.S. 249, 263 (1994) (Souter, J., concurring) (noting that "we have previously interpreted ... generally applicable statutes so as to avoid First Amendment problems," citing Noerr as an example).

${ }^{209}$ For a rare judicial opinion recognizing this distinction, see Cardtoons, L.C. v. Major League Baseball Players Ass’n, 208 F.3d 885, 889-90 (10th Cir. 2000) (en banc) (“The logical dilemma in applying Noerr-Pennington outside of the antitrust context is that Noerr's first rationale for immunity—an interpretation of the Sherman Act—is not present.”).
} 
condemn speech that is protected by the First Amendment. In many scenarios, the First Amendment does not protect speech that is intentionally false or deceptive, ${ }^{210}$ such as outlandish claims for patent infringement damages intended to elicit nuisance-value settlements from small or unsophisticated businesses or organizations. The law can therefore condemn those statements without violating the patent holder's constitutional rights.

Although the Supreme Court has recently suggested that false statements are not categorically exempt from First Amendment protection, ${ }^{211}$ the Court has reiterated that false statements may be condemned when they produce or are likely to produce "specific harm to identifiable victims," ${ }^{212}$ such as those under the common law torts of fraud and defamation. The types of false statements commonly made during patent enforcement, such as misrepresentations about the strength of the patents or how many other businesses or organizations have already licensed the patents, can cause numerous tangible harms. An accused infringer, for instance, might be intimidated into purchasing an unnecessary license. Also, if the false statements are directed toward end users, the manufacturer of the relevant product might lose sales or suffer damage to its reputation. Although the First Amendment may impose some limits on the patent enforcement conduct that may be condemned, ${ }^{213}$ requiring objective baselessness as a prerequisite to all claims, as the Federal Circuit

\footnotetext{
${ }^{210}$ See Va. State Bd. of Pharmacy v. Va. Citizens Consumer Council, Inc., 425 U.S. 748, 771 (1976) ("Untruthful speech, commercial or otherwise, has never been protected for its own sake.”); see also Illinois v. Telemarketing Assocs., Inc., 538 U.S. 600, 612 (2003) (“[T]he First Amendment does not shield fraud.”).

${ }^{211}$ United States v. Alvarez, 132 S. Ct. 2537, 2545 (2012) (plurality opinion).

${ }^{212}$ See id. at 2554 (Breyer, J., concurring in the judgment); see also id. at 2545 (plurality opinion) (noting that prior decisions in which the Court held false statements not to be protected by the First Amendment involved "defamation, fraud, or some other legally cognizable harm associated with a false statement, such as an invasion of privacy or the costs of vexatious litigation").

${ }^{213}$ For instance, one commentator has argued that statutes requiring particular information to be included in a demand letter violate constitutional restrictions on compelled speech. See Hearing on H.R. _ , A Bill to Enhance Federal and State Enforcement of Fraudulent Patent Demand Letters Before the H. Subcomm. on Commerce, Mfg. \& Trade of the H. Comm. on Energy \& Commerce, 113th Cong. 3-4 (May 22, 2014) (statement of Adam Mossoff, Professor of Law, George Mason Univ. Sch. of Law), available at http://docs.house.gov/ meetings/IF/IF17/20140522/102255/HHRG-113-IF17-Wstate-MossoffA-20140522.pdf [hereinafter Mossoff].
} 
does, seems to provide defendants with more protection than the Constitution actually mandates. ${ }^{214}$

The Supreme Court's most recent decision involving the Petition Clause, Borough of Duryea v. Guarnieri, ${ }^{215}$ supports the notion that Noerr immunity should not apply to non-antitrust claims. In that case, Guarnieri had been fired from his position as the borough's chief of police, but he filed a union grievance and was reinstated. ${ }^{216}$ After Guarnieri's reinstatement, the borough issued eleven directives instructing Guarnieri in the performance of his duties. ${ }^{217}$ Guarnieri then sued the borough, claiming that his grievance was a petition protected by the First Amendment and that the directives were impermissible retaliation for his constitutionally protected activity. ${ }^{218}$ On appeal, the Third Circuit applied a standard derived from Noerr and held that Guarnieri was immune from retaliation so long as his grievance was not a sham. ${ }^{219}$ The Supreme Court, however, refused to apply the sham standard to determine whether Guarnieri's grievance was protected by the First Amendment. ${ }^{220}$ Instead, the Court analogized to McDonald and held that the same test used to determine whether public employees' speech is protected by the Speech Clause should apply to those employees' claims under the Petition Clause. ${ }^{221}$ The Guarnieri Court's reliance on Speech Clause precedent-rather than the sham exception-to resolve a Petition Clause

\footnotetext{
${ }^{214}$ See generally Robert A. Zauzmer, Note, The Misapplication of the Noerr-Pennington Doctrine in Non-Antitrust Right to Petition Cases, 36 Stan. L. Rev. 1243, 1262 (1984) (arguing that Noerr should not be applied in non-antitrust cases). For a broader argument that courts should "employ first amendment principles developed in free speech cases to guide application of the Noerr-Pennington doctrine," including in antitrust cases, see Fischel, supra note 194 , at 100 .

215 131 S. Ct. 2488 (2011).

${ }^{216}$ Id. at 2492.

${ }^{217}$ Id. The directives included statements such as " $[\mathrm{t}]$ he police car is to be used for official business only" and "the Duryea municipal building is a smoke free building and . . . the police department is not exempt.” Id. (internal quotation marks omitted).

${ }^{218}$ Id.

${ }^{219}$ See Guarnieri v. Duryea Borough, 364 F. App’x 749, 753 (3d Cir. 2010) (citing San Filippo v. Bongiovanni, 30 F.3d 424, 440 (3d Cir. 1994), in turn citing Cal. Motor Transp. Co. v. Trucking Unlimited, 404 U.S. 508 (1972); United Mine Workers of Am. v. Pennington, 381 U.S. 657 (1965); E. R.R. Presidents Conference v. Noerr Motor Freight, Inc., 365 U.S. 127 (1961)).

${ }^{220}$ Guarnieri, 131 S. Ct. at 2495.

${ }^{221}$ Id. Public employees' speech is protected by the Speech Clause only if it is on a matter of public concern. See id. at 2493 (citing Connick v. Myers, 461 U.S. 138, 147 (1983)).
} 
claim again suggests that Noerr has limited relevance outside of antitrust law.

Case law assessing the First Amendment implications of the Fair Debt Collection Practices Act ("FDCPA") provides a final illustration of what should be Noerr's limited reach outside of antitrust cases. The FDCPA prohibits debt collectors, including attorneys engaged in litigation, ${ }^{222}$ from making false, deceptive, or misleading representations ${ }^{223}$-much like the new state statutes condemn similar representations made in connection with patent enforcement. Defendants to FDCPA claims have argued that it violates the First Amendment to penalize the filing of court pleadings unless those pleadings are objectively baseless under Noerr. ${ }^{224}$ But the lower federal courts have rejected that argument, holding that, under cases such as McDonald, intentional misrepresentations are simply not protected by the Petition Clause, regardless of the merit of the underlying claim. ${ }^{225}$

\section{The FEDERAL CiRCUIT ON PATENT “PREEMPTION”}

In the thirty years since its creation, the Federal Circuit has developed a line of case law substantially restricting the states' ability to regulate patent enforcement. Although the Federal Circuit has sometimes framed those decisions as involving preemption under the Supremacy Clause, the core issue is actually petitioning immunity under the First Amendment. In more recent opinions, the Federal Circuit has begun to rectify that mischaracterization, but confusion as to the constitutional basis for limiting state authority has caused the court to ignore difficult underlying questions about the proper scope of patent holders' immunity from civil liability. For example, should the stringent "sham litigation" test developed in antitrust cases such as Noerr apply to non-antitrust claims challenging patent enforcement? Should the First Amendment right to petition "the government" protect pre-litigation communications from one private party to another? The stakes surrounding these questions are high, for if the First Amendment requires that patent holders receive

\footnotetext{
${ }^{222}$ See Heintz v. Jenkins, 514 U.S. 291, 292 (1995).

${ }^{223} 15$ U.S.C. § 1692e (2012).

${ }^{224}$ See, e.g., Hartman v. Great Seneca Fin. Corp., 569 F.3d 606, 615 (6th Cir. 2009).

${ }^{225}$ See id. at 616; see also Sayyed v. Wolpoff \& Abramson, 485 F.3d 226, 229 (4th Cir. 2007) (rejecting the argument that "an absolute common law immunity attaches to "any statements made during the course of judicial proceedings"” and therefore immunizes lawyers' litigation activity from the FDCPA).
} 
broad, Noerr-like immunity for all communications related to patent enforcement, then governments - both state and federal-are largely powerless to engage the problem that has captured the attention of policymakers and the public: demand letters that contain plausible allegations of infringement but that also contain statements that are deceptive or false.

\section{A. Immunity for Patent Holders}

Federal law has long protected the right of patent holders to make "good faith" allegations of patent infringement. Yet the Federal Circuit has turned what was initially a flexible standard grounded in equity into a rigid, two-part test that is exceedingly difficult for plaintiffs to satisfy.

\section{Equitable Roots of Good Faith Immunity}

The principle that courts will condemn only bad faith assertions of patent infringement, and that good faith assertions of infringement are therefore immune from civil liability, can be traced back to at leat the nineteenth century. A leading example is Emack v. Kane, decided in $1888 .^{226}$ In that case, the plaintiff Emack and the defendant Kane were competing manufacturers of writing slates for school children. ${ }^{27}$ Kane sent several letters to the dealers who purchased the slates for resale to school districts, claiming that Emack's slate infringed a patent owned by Kane and threatening litigation against the dealers. ${ }^{228}$ The letters noted, among other things, that Kane had retained attorneys who had "an extensive and very successful" practice "in prosecuting infringement cases," that Kane intended to hold dealers who sold the infringing slate responsible for "royalt[ies] and damages," and that Kane "expect[ed] to commence some suits" within the next few months. ${ }^{229}$

On Emack's request, the court enjoined Kane from sending additional letters. The court found that the letters were "intended to intimidate" Emack's customers, and that the threats of suit were made "with a malicious intent to injure and destroy [Emack's] business." ${ }^{230}$ In addition, the court found that Kane "did not intend to prosecute" his threatened suits,

${ }^{226} 34$ F. 46 (C.C.N.D. Ill. 1888).

${ }^{227}$ Id. at 47.

${ }^{228}$ See id. at $47-48$.

${ }^{229}$ Id. at 48.

${ }^{230}$ Id. at 50. 
noting that Kane had actually sued three of Emack's customers, but then voluntarily dismissed the claims because Kane "knew that [he] could not sustain the suits upon their merits." ${ }^{231}$ Therefore, the court concluded, the "threats made ... . were not made in good faith." 232

Although some courts initially refused to follow Emack and grant injunctions against bad faith assertions of infringement, ${ }^{233}$ the case eventually came to be the touchstone for the courts' power to enjoin assertions of patent infringement. ${ }^{234}$ Early-twentieth-century commentators, reviewing the relevant case law, also concluded that courts had the equitable power to enjoin assertions of infringement made in bad faith. ${ }^{235}$ That rule was applied by numerous courts prior to the creation of the Federal Circuit in 1982. ${ }^{236}$

Although good faith has been called an "elusive idea," taking on different meanings in different contexts, ${ }^{237}$ good faith in patent enforcement traditionally referred to a subjective concept: that the speaker "sincerely believe[d] in the truth of his statement." ${ }^{238}$ In the early cases, a

${ }^{231}$ Id. at $49-50$.

232 Id. at 49.

233 See, e.g., Marlin Firearms Co. v. Shields, 64 N.E. 163, 166-67 (N.Y. 1902) (dismissing Emack as "a decision by a single judge"); see also 2 James L. High, A Treatise on the Law of Injunctions 775 (Chicago, Callaghan \& Co. 3d ed. 1890) (noting conflicting decisions); Albert H. Walker, Text-Book of The Law of Patents for Inventions § 585a, at 648-50 (John H. Hilliard \& Eugene Eblé eds., 5th ed. 1917) (similar).

${ }^{234}$ See 2 Louis Altman \& Malla Pollack, Callmann on Unfair Competition, Trademarks, and Monopolies § 11:31, at 11-140-43 (4th ed. 2008).

${ }^{235}$ See, e.g., 2 John Norton Pomeroy, A Treatise on Equitable Remedies § 2051 \& n.6 (2d ed. 1919) (discussing cases on "the injunction of intimidating circulars" regarding patent rights and noting that "sending out circulars in good faith will not be enjoined"); Roscoe Pound, Equitable Relief Against Defamation and Injuries to Personality, 29 Harv. L. Rev. 640, 655 n.41 (1916) (“[T] ing infringement of a patent and threatening purchasers from plaintiff with legal proceedings, where such circulars are published with no intention of suing for the alleged infringement or in pure malice.").

${ }^{236}$ See Annotation, Right to Enjoin Threats of Suits for Alleged Infringement of Patent, 98 A.L.R. 671, 671-81 (1935) (collecting cases); Mark S. Bicks, Threatening to Sue for Patent Infringement: Unfair Competition and Antitrust Consequences, 59 J. Pat. Off. Soc’y 302, 303-14 (1977) (same).

${ }^{237}$ Roger Brownsword et al., Good Faith in Contract: Concept and Context, in Good Faith in Contract: Concept and Context 1, 3 (Roger Brownsword et al. eds., 1999).

${ }^{238}$ Altman \& Pollack, supra note 234, § 11:10, at 11-40-41 \& n.14 (citing cases); see also Handgards, Inc. v. Ethicon, Inc., 601 F.2d 986, 993 (9th Cir. 1979) (“'Bad faith’ . . is a subjective state of mind the existence of which, while not susceptible to certain proof, easily can spring from suggestive and weakly corroborative circumstances.”); Bicks, supra note 236, at 
common basis for finding that the defendant lacked a sincere belief in its claims of patent infringement was that the defendant had threatened to file suit but never did so. ${ }^{239}$ Conversely, when the patent holder followed its threats with an infringement suit, courts refused to find bad faith. ${ }^{240}$

It should be noted that many of those cases were decided before Congress passed the Declaratory Judgment Act in 1934, so the accused infringers had no avenue to alleviate their uncertainty about whether they were infringing. ${ }^{241}$ In a case decided after the Act was passed, the Second Circuit emphasized that a delay in bringing suit, standing alone, would not justify a finding of bad faith. ${ }^{242}$ Rather, the court ruled that a plaintiff would need to present "other evidence indicating a lack of honest belief in the legal rights asserted," citing as an example a case in which there was uncontradicted evidence that the patent holder's infringement claim was meritless. ${ }^{243}$

As the Second Circuit's decision suggested, an analysis of a patent holder's good or bad faith often included both objective and subjective considerations. ${ }^{244}$ Courts in the pre-Federal Circuit era would consider the objective merit of the patent holder's claim as evidence of the sincerity of the infringement allegations. ${ }^{245}$ But those courts did not require a plaintiff to prove both that the infringement allegations were baseless and made with knowledge of that baselessness, as the Federal Circuit requires today. Rather, they applied the good faith standard in a manner consistent with its equitable roots, flexibly using it to condemn decep-

303-04 ("The good faith involved refers to a state of mind and, in this context, means that the speaker sincerely and reasonably believes in the truth of his statements.").

${ }^{239}$ See, e.g., Racine Paper Goods Co. v. Dittgen, 171 F. 631, 635-36 (7th Cir. 1909); Adriance, Platt \& Co. v. Nat'l Harrow Co., 121 F. 827, 830 (2d Cir. 1903); A.B. Farquhar Co. v. Nat'l Harrow Co., 102 F. 714, 715 (3d Cir. 1900).

${ }^{240}$ See, e.g., Mitchell v. Int'l Tailoring Co., 169 F. 145, 146 (C.C.S.D.N.Y. 1909); Warren Featherbone Co. v. Landauer, 151 F. 130, 134 (C.C.E.D. Wis. 1903).

${ }^{241}$ On the history and passage of the Federal Declaratory Judgment Act, 28 U.S.C. $\S \S 2201-02$ (2012), see Richard H. Fallon, Jr. et al., The Federal Courts and the Federal System 800-01 (6th ed. 2009).

${ }^{242}$ Kaplan v. Helenhart Novelty Corp., 182 F.2d 311, 314 (2d Cir. 1950).

${ }^{243}$ Id. (citing Betmar Hats v. Young Am. Hats, 116 F.2d 956 (2d Cir. 1941)).

${ }^{244}$ Cf. U.C.C. § 1-201(20) (2014) (“'Good faith’ . . means honesty in fact and the observance of reasonable commercial standards of fair dealing.”).

${ }^{245}$ See, e.g., Int'l Indus. \& Devs. v. Farbach Chem. Co., 145 F. Supp. 34, 36 (S.D. Ohio 1956) ("The Court finds, as a matter of fact, that plaintiff's failure to introduce any evidence at trial to support its charge of infringement conclusively establishes bad faith and malice ....”); Emack v. Kane, 34 F. 46, 49 (C.C.N.D. Ill. 1888) (relying on Kane’s voluntary dismissal of three infringement suits as evidence of bad faith). 
tive patent enforcement tactics, such as alleging infringement when the patent holder had not actually inspected the accused infringer's product $^{246}$ or boasting that the patent's validity had been confirmed by a court when, in fact, prior cases had merely settled. ${ }^{247}$ The pliability of the good faith standard was captured by a commentator writing shortly before the creation of the Federal Circuit who observed that "[i]n determining whether a course of conduct in giving notice of patent rights and threatening patent infringement suits ... subjects the actor to liability ..., all the factors which manifest the actor's intent must be considered and balanced against one another." 248

\section{Good Faith in the Federal Circuit}

The Federal Circuit's early decisions suggested that good faith immunity was indeed a malleable concept. Mallinckrodt, Inc. v. Medipart, Inc. ${ }^{249}$ is the leading example. In that case, Mallinckrodt manufactured and sold to hospitals a patented medical device that was labeled "Single Use Only" and was packaged with an insert instructing that, after one use, the entire device should be discarded as hazardous biological waste. ${ }^{250}$ Some hospitals, rather than discarding the device, sold the used devices to Medipart for reconditioning and reuse. ${ }^{251}$ Mallinckrodt sued Medipart for patent infringement, but the district court held that Medipart's reconditioning was merely an act of repair, not reconstruction, and therefore did not infringe. ${ }^{252}$ The district court also enjoined Mallinckrodt from distributing a new notice to its hospital customers stating that violation of the single use restriction was patent infringement. ${ }^{253}$

On appeal, the Federal Circuit overturned the district court's ruling of noninfringement. ${ }^{254}$ The court also vacated the injunction, noting that "[a] patentee that has a good faith belief that its patents are being infringed violates no protected right when it so notifies infringers." ${ }^{255}$ As examples of "good faith" immunity in action, the Federal Circuit dis-

\footnotetext{
${ }^{246}$ See, e.g., Int'l Indus., 145 F. Supp. at 35-36.

247 See, e.g., Gerosa v. Apco Mfg. Co., 299 F. 19, 26 (1st Cir. 1924).

${ }^{248}$ Bicks, supra note 236, at 319.

${ }^{249} 976$ F.2d 700 (Fed. Cir. 1992).

${ }^{250}$ Id. at 702 .

${ }^{251}$ Id.

252 Id.

${ }^{253} \mathrm{Id}$.

${ }^{254}$ Id. at $709-10$

${ }^{255}$ Id. at 709.
} 
cussed the regional circuit case law predating the court's creation, observing that:

Infringement notices have been enjoined when the patentee acted in bad faith, for example by making threats without intending to file suit, or when the patentee sent notices indiscriminately to all members of the trade, or when the patentee had no good faith belief in the validity of its patent. ${ }^{256}$

In Mallinckrodt, the court did not discuss preemption because the case did not contain any claims created by state law. But in an early case in which the plaintiff sought to impose state law liability on a patent holder due to its enforcement tactics, the Federal Circuit incorporated both the flexible concept of good faith immunity discussed in Mallinckrodt and the Supreme Court preemption decisions summarized above. ${ }^{257}$ In that case, Dow Chemical Co. v. Exxon Corp., Dow filed a state law claim of tortious interference based on statements made by Exxon to Dow's current and prospective customers stating that polymers made by Dow infringed a patent owned by Exxon. ${ }^{258}$ In its tort suit, Dow alleged that Exxon did not have a good faith belief that the patent was infringed and that Exxon had obtained its patent through inequitable conduct before the Patent and Trademark Office ("PTO”). ${ }^{259}$ The district court dismissed Dow's claim, refusing to consider evidence of Exxon's inequitable conduct because, in the district court's view, it would have been improper to "reach beyond the scope of [the] given controversy to invalidate a patent" as part of a business tort case. ${ }^{260}$ The district court also ruled that Exxon, as the owner of a patent, which, under the Patent Act,

${ }^{256}$ Id. at 710 (citations omitted) (citing Int'l Indus. \& Devs., v. Farbach Chem. Co., 241 F.2d 246 (6th Cir. 1957); Magnetic Eng'g \& Mfg. Co. v. Dings Mfg. Co., 178 F.2d 866 (2d Cir. 1950); Betmar Hats, Inc. v. Young Am. Hats, Inc., 116 F.2d 956 (2d Cir. 1941)). The court could also have relied on the Supreme Court's decision in Walker Process Equipment, Inc. v. Food Machinery \& Chemical Corp., in which the Court held that a defendant violates the antitrust laws by "knowingly and willfully misrepresenting facts to the Patent Office" during prosecution, but that the patent holder's "good faith" (such as an "honest mistake") furnishes a complete defense. 382 U.S. 172, 177 (1965).

${ }^{257}$ See supra Subsection II.A.2.

258139 F.3d 1470, 1472 (Fed. Cir. 1998).

${ }^{259}$ Id. The doctrine of inequitable conduct permits a court to hold a patent unenforceable if, during prosecution, the patent applicant misrepresented or omitted information material to patentability with the specific intent to mislead or deceive the PTO. See Therasense, Inc. v. Becton, Dickinson \& Co., 649 F.3d 1276, 1287 (Fed. Cir. 2011) (en banc).

${ }^{260}$ Dow, 139 F.3d at 1472. 
is presumed to be valid, ${ }^{261}$ was also "presumed to be acting in good faith" when it "exercise[d] [its] right to exclude others from using the invention.”262

On appeal, the Federal Circuit reversed and allowed Dow's state law claim to go forward. ${ }^{263}$ In holding that Dow's claim was not preempted, the court noted that it was "difficult to fathom" how Dow's tortious interference claim could compromise any of the objectives of the federal patent laws identified in Kewanee (incentivizing invention, promoting disclosure, and protecting the public domain). ${ }^{264}$ Like the Supreme Court in Kewanee, the Federal Circuit in Dow also recognized the traditional role of the states in regulating this area of law, noting that "a key purpose behind" the ban on tortious interference "is the protection of the integrity of commercial contracts which ... 'traditionally are the domain of state law.", 265

In addition to its preemption analysis, the Federal Circuit in Dow made clear that the plaintiff's allegations satisfied the bad faith requirement discussed in Mallinckrodt. The court distinguished an earlier Federal Circuit opinion, which seemed to suggest that an unfair competition claim based on the assertion of patent rights could never succeed, ${ }^{266}$ by noting that "[t]he instant case ... concerns an allegation of bad faith enforcement of a reputedly unenforceable patent." ${ }^{267}$ Specifically, Dow al-

\footnotetext{
26135 U.S.C. § 282(a) (2012).

${ }^{262}$ Dow, 139 F.3d at $1472-73$.

${ }^{263}$ Id. at 1473 .

${ }^{264}$ Id. at 1475 (" $[\mathrm{I}] \mathrm{t}$ seems most improbable that an inventor would choose to forfeit the
} benefits of patent protection because of fear of the risk of being found tortiously liable based upon attempting to enforce a patent obtained by inequitable conduct.").

${ }^{265}$ Id. (quoting Aronson v. Quick Point Pencil Co., 440 U.S. 257, 262 (1979)). Although state law claims based entirely on a patent holder's inequitable conduct before the PTO are preempted under Federal Circuit law, see In re DDAVP Indirect Purchaser Antitrust Litig., 903 F. Supp. 2d 198, 215-16 (S.D.N.Y. 2012) (summarizing Federal Circuit decisions), the claim in Dow also involved allegations of "bad faith misconduct in the marketplace," specifically, the attempted enforcement of an unenforceable patent, and so was not preempted under that line of Federal Circuit cases, Dow, 139 F.3d at 1477.

${ }^{266}$ See Concrete Unlimited v. Cementcraft, Inc., 776 F.2d 1537, 1539 (Fed. Cir. 1985) (holding a patent invalid as obvious but reversing a finding of unfair competition without inquiring into good or bad faith, noting that the patent holder "had the right to exclude others from making, using, and selling the invention and to enforce those rights until the ... patent was held invalid" and that the patent holder "did only what any patent owner has the right to do to enforce its patent, and that includes threatening alleged infringers with suit”), cited in Dow, 139 F.3d at 1476.

${ }^{267}$ Dow, 139 F.3d at 1476. 
leged that Exxon "knew that its patent was unenforceable" when it made its statements to Dow's customers. ${ }^{268}$

Although the Federal Circuit in Dow engaged both the Supreme Court's preemption case law and the bad faith immunity rule, bad faith became the sole focus of the Federal Circuit's preemption analysis in its next significant case involving state law claims based on patent enforcement, Hunter Douglas, Inc. v. Harmonic Design. ${ }^{269}$ In that case, Harmonic and two of its licensees had informed purchasers of motorized window shades that those licensees - and not Hunter Douglas — had an exclusive license to sell window shades covered by Harmonic's patents. ${ }^{270}$ Hunter Douglas sued Harmonic and its licensees claiming that Harmonic's patents were invalid and unenforceable, and asserting several claims under California law, including unfair competition, injurious falsehood, negligence, and intentional and negligent interference with prospective economic advantage. $^{271}$

The Federal Circuit first rejected the defendants' field preemption argument, noting that "state unfair competition law regulates conduct in a different field from federal patent law" and that, in any case, "conflict preemption is a more precise means of determining which state law causes of action are preempted than the blunt tool of field preemption." ${ }^{272}$ Turning to conflict preemption, the Federal Circuit wrote, consistent with the Supreme Court's Supremacy Clause-based preemption decisions, that the key question was "whether the state law actions frustrate[d] 'the accomplishment and execution of the full purposes and objectives of Congress." "273 But rather than considering the purposes of federal patent law, such as those identified in Kewanee and Bonito Boats (as well as by the Federal Circuit itself in Dow), the court stated that to determine preemption, "we assess a defendant's allegedly tortious conduct." 274 The court elaborated: "If a plaintiff bases its tort action on conduct that is protected or governed by federal patent law, then the plaintiff may not invoke the state law remedy, which must be preempted for conflict with federal patent law." ${ }^{275}$ Then, citing Mallinckrodt, the court

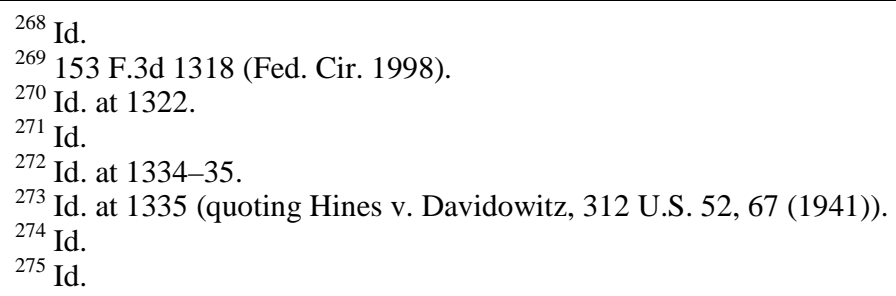


noted: “[F]ederal patent law bars the imposition of liability for publicizing a patent in the marketplace unless the plaintiff can show that the patent holder acted in bad faith." ${ }^{276}$ Ultimately, the court remanded the case for the district court to analyze preemption under the bad faith standard. ${ }^{277}$

Hunter Douglas marked the first time that the Federal Circuit equated bad faith with conflict preemption under the Supremacy Clause. Yet the bad faith standard was not created as a rule of preemption. Indeed, shortly after deciding Hunter Douglas, the Federal Circuit held that plaintiffs pursuing claims under federal law based on the defendant's patent enforcement conduct - and therefore not raising any issue of preemptionmust also prove the defendant's bad faith. ${ }^{278}$ More importantly, bad faith was originally a flexible concept that allowed courts to police unfair or deceptive assertions of patent rights while protecting legitimate claims of patent infringement. But, as discussed next, the Federal Circuit has turned that concept into a rigid, two-part test that is very difficult for plaintiffs to satisfy.

\section{B. Equating Bad Faith with Noerr Immunity}

In the wake of Hunter Douglas, the Federal Circuit began to evolve its new bad faith "preemption" standard into a rule resembling the Noerr doctrine's sham litigation test. For example, in a decision issued four months after Hunter Douglas, the court held that the objective accuracy of infringement allegations shielded a patent holder from a state law claim of intentional interference with existing and potential business relationships. ${ }^{279}$ Although the Noerr doctrine also immunizes objectively accurate statements from serving as the basis for liability, the Federal Circuit still framed its holding as grounded in the bad faith standard, asserting - without any citation - that “[a]lthough 'bad faith' may encompass subjective as well as objective considerations.... a competitive commercial purpose is not of itself improper, and bad faith is not supported when the information is objectively accurate."280 Accordingly, the court continued, "a threshold showing of incorrectness or falsity, or

\footnotetext{
${ }^{276}$ Id. at 1336.

${ }^{277}$ Id. at 1337.

${ }^{278}$ Zenith Elecs. Corp. v. Exzec, Inc., 182 F.3d 1340, 1353 (Fed. Cir. 1999) (involving a claim of unfair competition under the Lanham Act).

${ }^{279}$ Mikohn Gaming Corp. v. Acres Gaming, 165 F.3d 891, 898 (Fed. Cir. 1998).

${ }^{280}$ Id. at 897.
} 
disregard for either, is required in order to find bad faith in the communication of information about the existence or pendency of patent rights." 281

In Golan v. Pingel Enterprise, Inc., the court again raised the bar for plaintiffs seeking to impose liability for communications regarding patent infringement by holding that plaintiffs must prove bad faith by clear and convincing evidence. ${ }^{282}$ The court also bifurcated the bad faith standard into a two-element test, holding that an accused infringer may impose liability on a patent holder only if "the infringement allegations are objectively false" and "the patentee made them in bad faith, viz., with knowledge of their incorrectness or falsity, or disregard for either." ${ }^{283}$ In adopting the heightened standard of proof and bifurcating the immunity test into objective and subjective components, the Federal Circuit brought the bad faith rule even closer to the sham litigation test under Noerr and its progeny. Although the Federal Circuit cited no authority for adopting the clear and convincing evidence requirement, several courts of appeals, including the Federal Circuit, have held that antitrust plaintiffs seeking to strip a defendant of Noerr immunity must prove that litigation was a sham by clear and convincing evidence. ${ }^{284}$

The court finally drew an explicit link between its bad faith preemption doctrine and Noerr immunity in Globetrotter Software, Inc. v. Elan Computer Group, Inc. ${ }^{285}$ In that case, the plaintiff, Greer, who was the majority shareholder, chairman, and CEO of Elan, was negotiating an agreement with Rainbow Technologies, Inc. in which Rainbow would purchase all outstanding shares of Elan and provide Greer with a twoyear employment contract. ${ }^{286}$ During the negotiations, Globetrotter's CEO sent an e-mail to Rainbow's CEO suggesting that Rainbow investigate whether Elan's products infringed Globetrotter's patents. ${ }^{287}$ Globetrotter also sent two letters directly to Greer alleging that Elan infringed Globetrotter's patents. ${ }^{288}$ Based on those communications, Greer

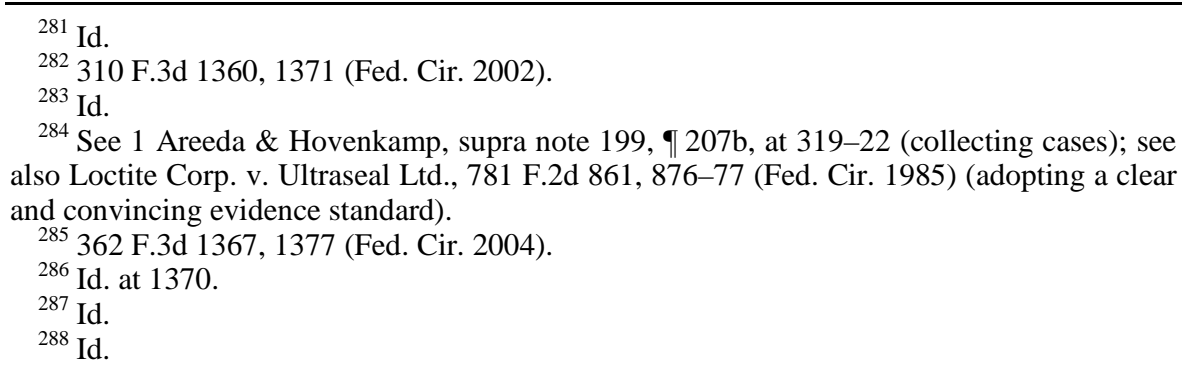


sued Globetrotter and its CEO under state law for tortious interference with prospective economic advantage and unfair competition. ${ }^{289}$

The Federal Circuit held the state law claims preempted. According to the court, Greer had improperly attempted to avoid preemption "only through attempts to demonstrate subjective bad faith,”290 such as by arguing that "the timing of Globetrotter's e-mail and letters alleging infringement shows that Globetrotter sought only to interfere with Rainbow's pending acquisition of Elan and agreement with Greer." 291 Rather, the court explained, to prove bad faith, a plaintiff must show "that the claims asserted were objectively baseless." "292 The court based the requirement of objective baselessness on the "jurisprudential background of the bad faith standard," which it found not in the Supremacy Clause (as would be the case for a rule that is truly about preemption) but in antitrust cases such as Noerr and, in particular, Professional Real Estate Investors, the decision in which the Supreme Court articulated the twoelement sham litigation test. ${ }^{293}$

In discussing those cases, the Federal Circuit acknowledged that there is some uncertainty about whether Noerr immunity, given its grounding in the First Amendment right "to petition the government," covers documents that are not actually filed in court, such as the e-mail and letters in Globetrotter. Rather than confronting that difficult question, however, the court simply observed that "our sister circuits, almost without exception, have applied the Noerr protections to pre-litigation communications." ${ }^{294}$ Likewise, on the issue of whether Noerr immunity should be available to defendants faced with non-antitrust claims, such as the tort and unfair competition claims asserted in Globetrotter, the court noted that "in another line of cases, our sister circuits have also applied the Noerr-Professional Real Estate line of cases to bar state-law liability (as opposed to federal antitrust liability)."295

Thus, the Federal Circuit has begun to acknowledge that its "preemption" decisions are based not on the Supremacy Clause, but on the Noerr

\footnotetext{
${ }^{289}$ Id.

${ }^{290}$ Id. at 1375.

${ }^{291}$ Id.

${ }^{292} \mathrm{Id}$.

${ }^{293} \mathrm{Id}$.

${ }^{294}$ Id. at 1376.

${ }^{295} \mathrm{Id}$.
} 
doctrine of petitioning immunity. ${ }^{296}$ Yet the Federal Circuit's case law is still unsatisfying in several respects. Most notably, the court has abandoned, without explanation, the flexible, equitable bad faith standard and replaced it with the rigid, two-part sham test articulated by the Supreme Court in Professional Real Estate Investors. ${ }^{297}$ To be sure, many federal courts of appeals have, like the Federal Circuit, applied the sham litigation test to all types of civil claims, not just antitrust claims. ${ }^{298}$ But the Federal Circuit in Globetrotter did not even analyze whether that expansion was warranted. It simply noted that many other courts had applied Noerr broadly, and went along with them. As a consequence, the Federal Circuit did not engage the potentially important distinction between filings in litigation (that is, actual petitions to the government) and prelitigation communications or notices to the trade, which are not directed to the government and that therefore would seem to be unprotected by the Petition Clause. Furthermore, as a practical matter, the sham litigation test as currently applied by the Federal Circuit is almost impossible for plaintiffs to satisfy. By my count, since Globetrotter, the Federal Circuit has barred the state law claims in all but one case raising the issue. $^{299}$

${ }^{296}$ Cf. id. at 1377 ("Our decision to permit state-law tort liability for only objectively baseless allegations of infringement rests on both federal preemption and the First Amendment.”).

${ }^{297}$ It should be noted that this shift is consistent with the Federal Circuit's often-discussed preference for bright-line rules over flexible standards. See, e.g., John R. Thomas, Formalism at the Federal Circuit, 52 Am. U. L. Rev. 771, 773-74 (2003). Likewise, preemption is not the only non-antitrust area in which the Federal Circuit has, controversially, applied a Noerr-like objective/subjective test. See, e.g., Octane Fitness, LLC v. ICON Health \& Fitness, Inc., 134 S. Ct. 1749, 1757 (2014) (overturning Federal Circuit case law that had required a prevailing party seeking attorneys' fees under the Patent Act to prove that its opponent's case was both objectively baseless and pursued in subjective bad faith); Halo Elecs. v. Pulse Elecs., 769 F. 3d 1371, 1384 (Fed. Cir. 2014) (O’Malley, J., concurring) (arguing that the court should reconsider en banc its application of an objective/subjective test for willful infringement).

${ }^{298}$ See supra note 198.

${ }^{299}$ See Matthews Int'l Corp. v. Biosafe Eng'g, 695 F.3d 1322, 1332 (Fed. Cir. 2012); Contech Stormwater Solutions v. Baysaver Techs., 310 F. App’x 404, 409 (Fed. Cir. 2009); 800 Adept, Inc. v. Murex Sec., Ltd., 539 F.3d 1354, 1372 (Fed. Cir. 2008); Judkins v. HT Window Fashion Corp., 529 F.3d 1334, 1339-40 (Fed. Cir. 2008); Dominant Semiconductors Sdn. Bhd. v. OSRAM GmbH, 524 F.3d 1254, 1264 (Fed. Cir. 2008); GP Indus. v. Eran Indus., 500 F.3d 1369, 1375-76 (Fed. Cir. 2007); Serio-US Indus. v. Plastic Recovery Techs. Corp., 459 F.3d 1311, 1321 (Fed. Cir. 2006). But see Breckenridge Pharm., Inc. v. Metabolite Labs., Inc., 444 F.3d 1356, 1369 (Fed. Cir. 2006) (reversing summary judgment, holding that "the question of whether [the patent holder's] statements ... . were 'objectively baseless' is genuinely disputed”). 
Finally, the Federal Circuit's "preemption” analysis, grounded in the sham litigation test, ignores the federalism concerns that a true preemption analysis would engage. For example, the Supreme Court has often articulated a presumption against preemption, stating that when addressing preemption questions "we begin our analysis 'with the assumption that the historic police powers of the States [are] not to be superseded by [a] Federal Act unless that was the clear and manifest purpose of Congress." " ${ }^{300}$ But the Federal Circuit has applied precisely the opposite presumption in its decisions involving state law claims, writing that "a party attempting to prove bad faith on the part of a patentee enforcing its patent rights has a heavy burden to carry." ${ }^{301}$ The Federal Circuit's invocation of Noerr as a preemption principle is also ironic given the Supreme Court's holding in Parker v. Brown that the Sherman Act (the statutory origin of Noerr immunity) was not intended to limit the authority of state governments or state officials. ${ }^{302}$ More broadly, there is deep tension between the sham litigation standard, which bars the government from condemning any but the most frivolous acts of patent enforcement, and many states' emerging interest in regulating demand letters and other assertions of patent infringement. The next Part revisits the new state laws and recent state law enforcement actions to show just how little power the states - and the federal government-have under current Federal Circuit doctrine.

\section{IMPLICATIONS OF CURRENT DOCTRINE}

Questions about the appropriate doctrinal basis for limiting government power to regulate patent enforcement-the Supremacy Clause, the Noerr doctrine, or the long-standing good faith rule-are not merely academic. As discussed above, the Supremacy Clause arguably gives the

\footnotetext{
${ }^{300}$ Altria Grp., Inc. v. Good, 555 U.S. 70, 77 (2008) (quoting Rice v. Santa Fe Elevator Corp., 331 U.S. 218, 230 (1947)). Some Justices dispute whether this presumption is warranted. See, e.g., Wyeth v. Levine, 555 U.S. 555, 624 (2009) (Alito, J., dissenting, joined by Roberts, C.J., and Scalia, J.) (“[T]he 'presumption against pre-emption' is [not] relevant to the conflict pre-emption analysis. ... [T] he sole question is whether there is an 'actual conflict' between state and federal law; if so, then pre-emption follows automatically by operation of the Supremacy Clause.”).

301800 Adept, 539 F.3d at 1370.

302 Parker v. Brown, 317 U.S. 341, 350-51 (1943). For a summary of the complex antitrust doctrine of "state action” immunity, see 1A Areeda \& Hovenkamp, supra note 199, ๆๆ 22131 , at $46-268$.
} 
states authority to condemn deceptive schemes of patent enforcement. ${ }^{303}$ The rule of good faith immunity, as understood prior to the Federal Circuit's creation, would limit that authority somewhat, but the Federal Circuit's expansive application of Noerr immunity renders the states-and the federal government-almost powerless. To properly frame a normative analysis of current Federal Circuit doctrine, it is worth highlighting several practical implications of the status quo for government efforts to address questionable tactics of patent enforcement.

\section{A. A Legal Right to Lie?}

A recent case from the Northern District of Illinois involving an infamous "Wi-Fi troll," Innovatio IP Ventures, best illustrates the nearly boundless immunity that patent holders have under current Federal Circuit doctrine. In that case, Innovatio sent letters to more than 8,000 end users of Wi-Fi technology, such as restaurants and hotels, accusing them of patent infringement. ${ }^{304}$ In response, the manufacturers of the hardware involved sued Innovatio, asserting a claim under the federal RICO statute and several claims under California state law, including unfair competition, civil conspiracy, breach of contract, and tortious interference. ${ }^{305}$ The manufacturers alleged that Innovatio's letters not only misrepresented the merits of the infringement claims, but also that the letters contained numerous false statements, including statements that Innovatio had "successfully licensed thousands of business locations under the ... [p]atents," that Broadcom (the original owner of the patents) had "generat[ed] in excess of \$1 Billion in settlements and license fees," and that "the validity of many claims of the ... patents ha[d] been confirmed by both the Federal Circuit and the United States Patent Office, via both judicial and re-examination proceedings." 306 The complaint alleged that those statements "grossly misrepresent[ed]" the number of licenses Innovatio had granted, that only one of the over thirty patents asserted had actually had its validity confirmed through reexamination, and that most of the $\$ 1$ billion in settlements and license fees that Innovatio claimed came from one \$891 million payment that one company had reportedly

\footnotetext{
${ }^{303}$ See supra Subsection II.A.3.

${ }^{304}$ In re Innovatio IP Ventures, LLC Patent Litig., 921 F. Supp. 2d 903, 907 (N.D. Ill. 2013).

${ }^{305}$ Id. at 906

${ }^{306}$ Id. at $920-21$.
} 
paid Broadcom “as part of a broad settlement unrelated to Innovatio's licensing program.” ${ }^{307}$

On Innovatio's motion to dismiss, the court accepted the plaintiffs' allegations as true but still dismissed the complaint because it did not satisfy the sham litigation standard. ${ }^{308}$ Even though the complaint alleged that Innovatio had lied in its demand letters, the court ruled that, even if the complaint was correct about the falsity of Innovatio's statements, none of the statements were "sufficiently central to Innovatio's infringement claims" to make the licensing campaign a sham. ${ }^{309}$ Although the court acknowledged that, in some circumstances, misrepresentations can cause a party to forfeit immunity under Noerr, this rule, the court explained, is "limited to misrepresentations respecting the substance of the claim.” ${ }^{310}$ By contrast, Innovatio’s statements about its past licenses and prior confirmations of the patents' validity were "peripheral to the question of infringement” and did not strip Innovatio of immunity. ${ }^{311}$

In the wake of In re Innovatio IP Ventures, LLC Patent Litigation, a federal district court in Nebraska enjoined the state's attorney general from pursuing state law claims against MPHJ because the attorney general did not allege that MPHJ's theories of validity and infringement were objectively baseless. ${ }^{312}$ As discussed above, the attorney general had issued a cease-and-desist order enjoining MPHJ's law firm from "initiati[ng] ... new patent infringement enforcement efforts within the State of Nebraska," asserting that the firm had potentially violated Nebraska's consumer protection and deceptive trade practices statutes. ${ }^{313}$ In Activision TV, Inc. v. Bruning, MPHJ (along with Activision, another client of the same law firm) sought to enjoin the attorney general from enforcing the order, arguing that his action was preempted under Federal Circuit law. ${ }^{314}$ In response, the attorney general cited the "false and mis-

\footnotetext{
${ }^{307}$ Id.

${ }^{308}$ Id. at 922.

${ }^{309}$ Id. at 921.

${ }^{310}$ Id. (citing Balt. Scrap Corp. v. David J. Joseph Co., 237 F.3d 394, 401-02 (4th Cir. 2001); Cheminor Drugs, Ltd. v. Ethyl Corp., 168 F.3d 119, 124 (3d Cir. 1999); Kottle v. Nw. Kidney Ctrs., 146 F.3d 1056, 1060 (9th Cir. 1998)).

${ }^{311}$ Id. at $921-22$

${ }^{312}$ See Activision TV, Inc. v. Bruning, No. 8:13-cv-215, slip op. at 13-14 (D. Neb. Sept. 2, 2014)

${ }^{313}$ Letter from Jon Bruning, Att’y Gen. of Neb., to M. Brett Johnson, Partner, Farney Daniels LLP (July 18, 2013), available at http://www.essentialpatentblog.com/wp-content/ uploads/sites/234/2014/01/2013-07-18-AG-Cease-and-Desist-Order.pdf.

${ }^{314}$ Activision, slip. op. at 11.
} 
leading representations" contained in MPHJ's demand letters, ${ }^{315}$ such as MPHJ's statements that many businesses had already purchased licenses and that MPHJ intended to file suit against recipients who did not purchase a license. ${ }^{316}$ The court, however, held that to avoid preemption under Federal Circuit law, the attorney general had to show that the patent holder's theories of validity or infringement were objectively baseless. ${ }^{317}$ Because the attorney general had not alleged that MPHJ's patents were invalid or that the infringement allegations were inaccurate, the court ruled that the attorney general's enforcement actions under Nebraska law were not permitted under Federal Circuit law, regardless of any false or misleading statements in MPHJ's letters. ${ }^{318}$

Innovatio and Activision make clear that, so long as infringement allegations themselves are not objectively baseless, patent holders have, in essence, "a legal right to lie." ${ }^{19}$ Allowing patent holders to falsely threaten infringement litigation and to fabricate stories about the success of a licensing program enhances the ability of patent holders to intimidate accused infringers into settlement. This is particularly true when, as was the case in both Innovatio and Activision, the patent holder demands a settlement that is less than the cost of hiring a lawyer to investigatemuch less to litigate - the infringement allegations.

\section{B. Implications for the New State Statutes and State Law Enforcement Actions}

This broad immunity for pre-suit communications gives courts a clear path to find some of the new state statutes invalid and to limit the application of others. The Wisconsin statute is particularly vulnerable. Recall that Wisconsin's statute can be violated in two ways: (1) if the patent holder sends a demand letter that lacks the information required by the statute, the recipient asks for that information, and the patent holder does not provide the information within thirty days or (2) if the demand letter

\footnotetext{
${ }^{315}$ Id. at 13.

${ }^{316}$ See Brief in Opposition to Motion for Summary Judgment at 22-24, Activision, No. 8:13-cv-215 (D. Neb. Feb. 28, 2014).

${ }^{317}$ Activision, slip op. at 13 ("[T]he crucial issues to establish objective[] baselessness involve validity and infringement.”).

${ }^{318}$ Id. at $13-14$.

${ }^{319}$ Steven Seidenberg, Patent Trolls Getting First Amendment Protection for Their Demand Letters, A.B.A. J., May 2014, http://www.abajournal.com/magazine/article/patent_trolls_are_ getting_first_amendment_protection_for_demand_letters.
} 
"contain[s] false, misleading, or deceptive information." ${ }^{320}$ The portion of the statute requiring demand letters to contain specific information is almost certainly invalid under Federal Circuit law. The court has flatly stated that " $[t]$ he federal patent laws . . . bar state-law liability for communications concerning alleged infringement so long as those communications are not made in 'bad faith."”321 The Wisconsin statute, however, would subject a person making a good faith-indeed, an objectively accurate-assertion of patent infringement to state law liability for not including, for example, a list of other court proceedings involving the patent. ${ }^{322}$

Also vulnerable under current doctrine are the Wisconsin statute's prohibition on false, misleading, or deceptive information, ${ }^{323}$ and the prohibition on false threats of infringement litigation found in several states' statutes. ${ }^{324}$ As Innovatio and Activision suggest, patent holders may be permitted to make false statements so long as those statements do not relate to the issues of patent validity or infringement. Under Federal Circuit law, a state would be allowed to condemn letters that, for instance, threaten litigation based on a patent that was expired at the time of the alleged acts of infringement because the patent's expiration would make the infringement claim itself objectively baseless. ${ }^{325}$ But, under the reasoning of Innovatio and Activision, a state cannot outlaw all false statements in a letter asserting patent infringement nor can it condemn false threats of litigation. Those statements are peripheral to the question of infringement and, under current doctrine, are immunized from serving as the basis for civil liability.

\footnotetext{
${ }^{320}$ Wis. Stat. § 100.197(2)(b), (2)(c)(1)-(2) (2014).

${ }^{321}$ Globetrotter Software, Inc. v. Elan Computer Grp., 362 F.3d 1367, 1374-75 (Fed. Cir. 2004).

${ }^{322}$ See Wis. Stat. § 100.197(2)(a)(6); see also Mossoff, supra note 213, at 3-4 (suggesting that statutes requiring particular information to be included in a demand letter violate constitutional restrictions on compelled speech).

${ }^{323}$ Wis. Stat. § 100.197(2)(b); see also Utah Code Ann. § 78B-6-1903(2)(b)(vi) (LexisNexis 2014) (Vermont-style statute stating that "a false or misleading statement" in a demand letter can provide evidence of bad faith).

${ }^{324} 815$ Ill. Comp. Stat. 505/2RRR(b)(1) (2015); Okla. Stat. tit. $23 \S 112(A)(1)$ (2014); Tenn. Code Ann. § 29-10-102(a)(1) (2014); H.B. 589, Reg. Sess. § 2(1)(a) (Miss. 2015) (enacted); S.B. 39, 64th Leg. § 2(1)(a) (Mont. 2015) (enacted); see also Va. Code Ann. § 59.1215.2(B)(6) (2014) (Vermont-style statute suggesting that a finding of bad faith may be appropriate if "the person threatens legal action that ... is not intended to be taken").

${ }^{325}$ See, e.g., Ill. Comp. Stat. 505/2RRR(b)(3)(C).
} 
Statutes that follow Vermont's lead and outlaw "bad faith" assertions of patent infringement seem at first glance less susceptible to invalidation because the two-part sham litigation test is merely the Federal Circuit's gloss on the long-standing bad faith standard. ${ }^{326}$ But, as an initial matter, none of the statutes require courts to find bad faith by clear and convincing evidence, which the Federal Circuit has held is required to condemn patent enforcement conduct. ${ }^{327}$ More fundamentally, some of the statutory factors defining bad faith encompass conduct that the Federal Circuit has held is insufficient to support liability. For example, the Vermont statute suggests that a finding of bad faith is appropriate if " $t$ t]he claim or assertion of patent infringement is meritless, and the person knew, or should have known, that the claim or assertion is meritless.” 328 This factor is similar to the Federal Circuit's statement in Golan that a plaintiff can avoid preemption by showing "that the infringement allegations are objectively false, and that the patentee made them ... with knowledge of their incorrectness or falsity, or disregard for either." 329 Yet the Federal Circuit in Globetrotter subsequently held that it is not sufficient to show that infringement allegations were "meritless" or "false." Rather, they must be so baseless that no reasonable litigant could have expected success. ${ }^{330}$ In addition, the versions of the Vermont statute adopted in Idaho and Virginia make the patent holder's "subjective bad faith" a factor in determining whether the statute has been violated, ${ }^{331}$ but the Federal Circuit has made clear that "[s]ubjective considerations of bad faith are irrelevant if the [infringement] assertions are not objectively baseless." 332

In sum, although the state statutes outlawing bad faith assertions of infringement are perhaps not facially invalid, in application their scope could be limited by Federal Circuit case law extending Noerr to all civil claims based on any type of patent enforcement conduct, including pre-

\footnotetext{
${ }^{326}$ See GP Indus. v. Eran Indus., 500 F.3d 1369, 1374 (Fed. Cir. 2007) ("We have recently determined that a bad faith standard cannot be satisfied in the absence of a showing that the claims asserted were objectively baseless.” (citing Globetrotter, 362 F.3d at 1375)).

${ }^{327}$ Golan v. Pingel Enter., Inc., 310 F.3d 1360, 1371 (Fed. Cir. 2002).

${ }^{328}$ Vt. Stat. Ann. tit. 9, § 4197(b)(6) (2014).

329310 F.3d at 1371.

${ }^{330}$ Globetrotter, 362 F.3d at 1376. For the same reason, the Wisconsin statute's prohibition on false statements, Wis. Stat. § 100.197(2)(b) (2014), may be invalid even when applied to allegations of infringement because Globetrotter requires that those allegations be objectively baseless, not merely false.

${ }_{331}$ Idaho Code Ann. § 48-1703(2)(f) (2014); Va. Code Ann. § 59.1-215.2(B)(5) (2014).

${ }^{332}$ GP Indus. v. Eran Indus., 500 F.3d 1369, 1375 (Fed. Cir. 2007).
} 
suit communications. No court has definitively ruled on the constitutionality of any of the new state statutes, but MPHJ has filed a lawsuit seeking a declaration that Vermont's statute is unconstitutional, both facially and as applied. In a brief order issued as this Article was being prepared for publication, the district court denied the state's motion to dismiss, reasoning that MPHJ stated a plausible claim under both theories. ${ }^{333}$

Not only could Federal Circuit case law limit the impact of the new state statutes, it may impede state law enforcement actions against patent holders. Thus far, the most notable state law enforcement action is the suit filed by the Vermont attorney general against MPHJ alleging that MPHJ engaged in unfair and deceptive trade practices. ${ }^{334}$ The unfair trade practices cited in the complaint include: MPHJ stating that it would bring suit against the recipients of its demand letter when in fact MPHJ was "neither prepared nor likely to bring litigation,” MPHJ's use of lawyers to imply that it had performed a pre-suit investigation into the alleged infringement, MPHJ's pattern of targeting small businesses that lack the resources to conduct patent litigation, and MPHJ's use of shell corporations to hide the true owners of the patents. ${ }^{335}$ The deceptive trade practices cited in the complaint include MPHJ's statements that it would sue within two weeks if the recipient did not purchase a license and that its licensing program had received "a positive response from the business community." 336

Notably, although the complaint alleges that MPHJ "acted in bad faith by sending [its] letters to Vermont businesses," ${ }^{337}$ the complaint does not allege that the infringement allegations were made in bad faith. Indeed, the state asserted in support of its motion to remand the case to state court, and the district court agreed, that "[t]he State's claims do not challenge the validity or scope of MPHJ's patents nor do they require any determination of whether infringement has actually occurred." 338 Rather, the court noted, "the State is targeting bad faith conduct irrespective of

\footnotetext{
${ }^{333}$ MPHJ Tech. Invs., LLC v. Sorrell, No. 2:14-cv-191, 2015 WL 3505224, at *9 (D. Vt. June 3, 2015).

${ }^{334}$ See supra Section I.B.

${ }^{335}$ See Consumer Protection Complaint at 8-9, Vermont v. MPHJ Tech. Invs., LLC, No. 282-5-13wncv (Vt. Super. Ct. May 8, 2013), available at http://www.atg.state.vt.us/assets/files/ Vermont\%20v\%20MPHJ\%20Technologies\%20Complaint.pdf.

${ }^{336}$ Id. at 9-10 (quoting one of MPHJ's letters).

${ }^{337}$ Id. at 8.

${ }^{338}$ Vermont v. MPHJ Tech. Invs., LLC, No. 2:13-cv-170, 2014 WL 1494009, at *6 (D. Vt. Apr. 15, 2014).
} 
whether the letter recipients were patent infringers or not, on the basis that MPHJ's bad faith conduct would be unlawful even [if] MPHJ's patents were valid and the conduct was directed toward actual patent infringers." 339 Without an allegation that MPHJ's infringement claims were objectively baseless, however, the state's complaint appears strikingly similar to the complaint in Innovatio, which the district court dismissed because the alleged false statements were "peripheral to the question of infringement." 340

Forcing the state to prove not only the elements of its claim under state law but also that the underlying patent infringement suit was baseless will likely deter state officials from bringing similar enforcement actions in the future. State attorneys general have practically no experience litigating matters of federal patent law, such as validity and infringement. Moreover, it is very difficult to prove that infringement allegations were so baseless that no reasonable person in the patent holder's position could have expected to succeed. Patents are presumed to be valid, ${ }^{341}$ meaning that invalidity must be proved by clear and convincing evidence. ${ }^{342}$ Also, patent claim construction, which is often dispositive of infringement, is notoriously unpredictable. ${ }^{343}$ These factors make it reasonable for a patent holder to have some hope of success even on a weak claim of infringement. Thus, state attorneys general may find that current doctrine makes it futile to challenge patent enforcement schemes, whether under the new statutes or under pre-existing law.

\section{Implications for Federal Law and Law Enforcement}

Because the Federal Circuit has grounded its two-part "preemption" test in the Petition Clause of the First Amendment, the federal government also has limited power to combat questionable patent enforcement tactics. As part of an investigation into MPHJ, the Federal Trade Commission ("FTC") filed a complaint against the company alleging that it

\footnotetext{
${ }^{339}$ Id.

${ }^{340}$ In re Innovatio IP Ventures, LLC Patent Litig., 921 F. Supp. 2d 903, 922 (N.D. Ill. 2013).

34135 U.S.C. $\S 282(a)$ (2012).

${ }^{342}$ Microsoft Corp. v. i4i Ltd. P’ship, 131 S. Ct. 2238, 2242 (2011).

343 Dan L. Burk \& Mark A. Lemley, Fence Posts or Sign Posts? Rethinking Patent Claim Construction, 157 U. Pa. L. Rev. 1743, 1744-46 (2009). But see J. Jonas Anderson \& Peter S. Menell, Informal Deference: A Historical, Empirical, and Normative Analysis of Patent Claim Construction, 108 Nw. U. L. Rev. 1, 4-6 (2014) (noting that appellate reversal rates on the issue of claim construction have decreased in recent years).
} 
had engaged in deceptive trade practices in violation of Section 5 of the Federal Trade Commission Act. ${ }^{344}$ The FTC claimed that the company violated Section 5 in two ways. First, it alleged that MPHJ said it would "initiate legal action for patent infringement" if the recipient did not respond to its demand letters when, in fact, MPHJ was "not prepared to initiate legal action and did not intend to initiate legal action.”345 Second, the FTC alleged that MPHJ falsely or misleadingly stated "that substantial numbers of businesses who had received the . . . letters agreed to pay substantial compensation to license the ... [p]atents." 346

Because MPHJ settled with the FTC, the First Amendment implications of the FTC's investigation were never adjudicated. ${ }^{347}$ However, a court easily could have determined that the FTC's complaint infringed MPHJ's right to petition as interpreted by the Federal Circuit and the lower federal courts. The FTC's first theory was based on MPHJ's lack of subjective intent to file suit, which is insufficient under Federal Circuit law to impose civil liability on a patent holder. ${ }^{348}$ Moreover, that theory, as well as the theory that MPHJ misrepresented the number of businesses that had purchased licenses, could have run into the same problem as the plaintiffs in Innovatio and the Nebraska attorney general in Activision: attempting to impose liability based on false statements that had nothing to do with the merits of the infringement claims.

In response to concerns about patent holders targeting end users, Congress has begun to contemplate legislation that would regulate patent enforcement conduct. Under the courts' interpretation of the Petition Clause, however, Congress's options are limited. A recent bill, the Targeting Rogue and Opaque Letters ("TROL”) Act, defines several types of communications related to alleged patent infringement as unfair or

\footnotetext{
${ }^{344}$ FTC Complaint, supra note 1, at 9; see 15 U.S.C. § 45(a)(1) ("Unfair methods of competition in or affecting commerce, and unfair or deceptive acts or practices in or affecting commerce, are hereby declared unlawful.”).

${ }^{345}$ FTC Complaint, supra note 1 , at 8.

${ }^{346} \mathrm{Id}$.

${ }^{347}$ In January 2014, MPHJ sued the FTC seeking a declaration that the investigation violated the company's First Amendment rights, but the court dismissed the complaint without addressing the merits because, at the time, the FTC had not taken any final action. See MPHJ Tech. Invs., LLC v. FTC, No. 6:14-cv-11, slip op. at 6, 11-13 (W.D. Tex. Sept. 16, 2014).

${ }^{348}$ See Globetrotter Software, Inc. v. Elan Computer Grp., 362 F.3d 1367, 1375 (Fed. Cir. 2004) (refusing to impose liability where the plaintiff attempted to demonstrate only subjective bad faith).
} 
deceptive acts under Section 5 of the FTC Act. ${ }^{349}$ For example, the bill would make it unlawful to, "in bad faith," state or represent that "legal action for infringement of the patent will be taken against the recipient" or that "persons other than the recipient purchased a license for the patent asserted." 350 The bill then outlines three ways in which bad faith can be shown, defining the term as follows:

The term "bad faith" means . . . that the sender-

(A) made knowingly false or knowingly misleading statements, representations, or omissions;

(B) made statements, representations, or omissions with reckless indifference as to the false or misleading nature of such statements, representations, or omissions; or

(C) made statements, representations, or omissions with awareness of the high probability of the statements, representations, or omissions to deceive and the sender intentionally avoided the truth. ${ }^{351}$

Some members of Congress have objected that the bad faith requirement will make it too difficult for the FTC to prove that a patent holder violated the statute, ${ }^{352}$ but that requirement is, as this Article has shown, mandated by the Federal Circuit's interpretation of the Petition Clause. Moreover, even the narrow definition of bad faith in the bill may encompass conduct that is immunized under current law. For example, the bill condemns any misleading statement in a demand letter, including statements that are peripheral to the infringement allegations, such as braggadocio about past licensing success. Yet, as Innovatio and Activision illustrate, such peripheral misrepresentations cannot be the basis for civil liability under current law.

A bill recently introduced in the Senate, the Protecting American Talent and Entrepreneurship ("PATENT") Act, raises similar difficulties.

\footnotetext{
${ }^{349}$ Targeting Rogue and Opaque Letters Act of 2015, H.R. 2045, 114th Cong. § 2(a). A bill pending in the Senate contains provisions similar to the TROL Act. See Support Technology and Research for Our Nation's Growth (“STRONG”) Patents Act of 2015, S. 632, 114th Cong. §§ 201-04.

${ }^{350}$ H.R. $2045 \S 2(\mathrm{a})(1)(\mathrm{D}),(\mathrm{F})$.

${ }^{351}$ Id. § 5(1).

${ }^{352}$ See Markup of Targeting Rogue and Opaque Letters Act of 2014: Hearing Before the Subcomm. on Commerce, Mfg. \& Trade of the H. Comm. on Energy \& Commerce, 114th Cong. (Apr. 28-29, 2015) (remarks of Reps. Schakowsky (9:20), Eschoo (2:09:10), and Pallone (2:20:30)), available at https://www.youtube.com/watch?t=8049\&v=7EFOnDVuBYM.
} 
The bill would outlaw numerous specific actions taken by persons who engage in the "widespread sending" of demand letters, such as engaging in a pattern of falsely threatening infringement litigation, making statements related to patent validity, enforceability, or infringement that "lack a reasonable basis in fact or law," or sending letters "likely to materially mislead a reasonable recipient" because the letters do not contain information about the patent holder, the asserted patent, or the recipient's alleged infringement. ${ }^{353}$ Under the bill, these prohibitions would be enforced by the FTC through its existing authority. ${ }^{354}$

The PATENT Act contains many of the same vulnerabilities as the other statutes discussed thus far. For example, it condemns false threats of litigation, which the Federal Circuit has suggested cannot be done. Although the bill acknowledges the concept of objective baselessness by condemning assertions that lack a reasonable basis in fact or law, the Federal Circuit has held that objective baselessness alone is not sufficient to strip a patent holder of immunity - the patent holder also must know that the allegation is baseless or act in reckless disregard for whether the allegation is true or false.

In sum, reasonable minds might differ about whether policing unfair or deceptive patent assertions is a function that should be handled by an administrative agency, such as the FTC, or through legislation. Those who support a legislative solution might also reasonably disagree about the precise terms of any new statute and, of course, whether such a statute should be passed by Congress or by state legislatures. But the Federal Circuit's expansive immunity standard precludes all three branches of government at both the state and federal levels from regulating the enforcement tactic that is most troublesome: sending demand letters that contain weak (but not frivolous) allegations of infringement and that use misleading, deceptive, or false statements in an attempt to intimidate recipients into quickly purchasing a license. Fortunately, federal law already contains an alternative immunity standard that would allow governments to outlaw those tactics: the flexible good faith standard applied by courts before the Federal Circuit adopted its current, Noerr-based immunity rule.

\footnotetext{
353 Protecting American Talent and Entrepreneurship Act of 2015, S. 1137, 114th Cong. § 9(a).

${ }^{354}$ Id.
} 


\section{Rethinking Petitioning IMmunity in Patent Cases}

Although state governments and the federal government are increasingly interested in regulating patent enforcement, the Federal Circuit has left them powerless. Yet the court has offered no persuasive justification for extending the broad antitrust immunity conferred by Noerr to all civil claims challenging patent enforcement conduct. Accordingly, the Federal Circuit en banc or the Supreme Court should force a return to a narrower, more flexible immunity standard that accommodates the courts' historical practice of condemning unfair and deceptive acts of patent enforcement.

\section{A. Returning to Good Faith}

Some scholars have argued that Noerr should never protect litigation conduct as petitioning activity. ${ }^{355}$ They contend that Noerr immunity should be limited to its original context of petitions directed toward the legislative and executive branches. Under that view, the Supreme Court erred in cases such as California Motor Transport and Professional Real Estate Inventors, which immunized defendants from antitrust claims based on the pursuit of litigation. If that position is correct, then the Federal Circuit is almost certainly wrong in applying Noerr to claims that seek to impose civil liability based on patent enforcement activity. If documents that are actually filed in court are not protected by Noerr, then surely patent demand letters, which are ostensibly a precursor to the filing of litigation, should likewise not be entitled to Noerr immunity.

But even if Noerr does protect litigation or litigation-related conduct as petitioning activity, there is, as discussed above, a reasonable argument that defendants should not be able to invoke Noerr as a defense against claims not grounded in antitrust. ${ }^{356}$ The holding in Noerr was "a construction of the Sherman Act" adopted to avoid "important ... questions" about the right to petition, informed by the Sherman Act's purpose to regulate "business activity," not "political activity." ${ }^{357}$ Most civil claims challenging patent enforcement are not asserted under the antitrust laws, however. And the purpose behind laws on wrongful civil proceedings and abuse of process - unlike antitrust law-

\footnotetext{
${ }^{355}$ See Lemley \& McGowan, supra note 188, at 397.

${ }^{356}$ See supra text accompanying notes 201-21.

${ }^{357}$ E. R.R. Presidents Conference v. Noerr Motor Freight, Inc., 365 U.S. 127, 137-38 (1961).
} 
is plainly to regulate litigation conduct. Likewise, laws governing unfair competition are designed to ensure the accuracy of information in the marketplace, ${ }^{358}$ and so are plausibly aimed at eliminating false or deceptive allegations of patent infringement that influence the market. Disparagement claims similarly target false statements intended to cause pecuniary harm, ${ }^{359}$ so it is conceivable that false allegations of patent infringement come within the purpose of that tort. And the intent of the new state patent assertion statutes is obviously to regulate litigationrelated conduct. Thus, the statutory justification for Noerr immunity, that is, that regulation of litigation conduct is outside the purpose of the Sherman Act, is absent in the context of many civil claims used to challenge patent enforcement, leaving defendants reliant solely on the First Amendment rights to petition and to free speech. Case law under those constitutional provisions - unlike the Noerr doctrine-permits courts and legislatures to condemn false and deceptive statements, ${ }^{360}$ even if those statements are attached to plausible legal claims. ${ }^{361}$

When it comes to claims based on statements made in pre-litigation communications, such as demand letters, the case for conferring Noerr immunity is even weaker. The basic reasoning for extending Noerr to pre-litigation communications has been clearly articulated by the Fifth Circuit:

Given that petitioning immunity protects ... litigation, it would be absurd to hold that it does not protect those acts reasonably and normally

\footnotetext{
${ }^{358}$ See Peter S. Menell \& Suzanne Schotchmer, Intellectual Property Law, in 2 Handbook of Law and Economics 1473, 1536 (A. Mitchell Polinsky \& Steven Shavell eds., 2007).

${ }^{359}$ See Restatement (Second) of Torts § 623A (1977).

${ }^{360}$ See supra text accompanying notes $210-14$.

361 The Supreme Court has avoided deciding whether, under the Noerr doctrine itself, defendants may be stripped of liability for "fraud or other misrepresentations" made to a court. See Prof'l Real Estate Investors v. Columbia Pictures Indus., 508 U.S. 49, 61-62 n.6 (1993). To date, the lower courts have mostly concluded that, to strip a defendant of Noerr immunity, any misrepresentation must be so severe as to "deprive the litigation of its legitimacy." Kottle v. Nw. Kidney Ctrs., 146 F.3d 1056, 1060 (9th Cir. 1998); see also Cheminor Drugs, Ltd. v. Ethyl Corp., 168 F.3d 119, 123 (3d Cir. 1999) (refusing to consider intentional misrepresentation as an independent ground for stripping a party of Noerr immunity, noting that "[i]f the alleged misrepresented facts do not infect the core of [the] claim . ..., then the petition had an objective basis and will receive ... immunity"). That line of cases influenced the court's decision in Innovatio to immunize the patent holder's allegedly false statements about the reexamination of its patents and its previous licensing efforts. In re Innovatio IP Ventures, LLC Patent Litig., 921 F. Supp. 2d 903, 921 (N.D. Ill. 2013) (citing Kottle, 146 F.3d at 1060, and Cheminor, 168 F.3d at 124).
} 
attendant upon effective litigation. The litigator should not be protected only when he strikes without warning. If litigation is in good faith, a token of that sincerity is a warning that it will be commenced and a possible effort to compromise the dispute. ${ }^{362}$

Although pre-filing communications make it possible to resolve a dispute without calling on the public resources of the courts, there are reasons to pause before extending Noerr immunity to all pre-litigation communications. To begin with, there is the constitutional text. Assuming that Noerr immunity is based on the First Amendment, as the Federal Circuit has indicated, ${ }^{363}$ it is absurd to say that a letter between private parties is a "petition" to "the government" within the meaning of the Petition Clause. ${ }^{364}$ The Tenth Circuit, in a decision that represents a minority view, has held that "[a] letter from one private party to another private party simply does not implicate the right to petition.”365 But ignoring the constitutional text is usually justified based on the policy argument, embraced by the Fifth Circuit in the passage quoted above, that immunizing threats to sue encourages out-of-court settlement, saving the courts' time and effort. ${ }^{366}$

If, however, the sender is using the threat itself to extract a payment and has no intention to actually file suit, then it is not clear that the threat should be protected. ${ }^{367}$ Similarly, even if the infringement allegations made in a demand letter are considered to constitute petitioning activity protected by the First Amendment, ancillary statements that have nothing to do with the infringement claim seem less worthy of immunity, particularly when those ancillary statements are false or misleading or are designed to induce the recipient to purchase a license without retain-

${ }^{362}$ Coastal States Mktg. v. Hunt, 694 F.2d 1358, 1367 (5th Cir. 1983).

${ }^{363}$ Globetrotter Software, Inc. v. Elan Computer Grp., 362 F.3d 1367, 1377 (Fed. Cir. 2004).

364 See Marina Lao, Reforming the Noerr-Pennington Antitrust Immunity Doctrine, 55 Rutgers L. Rev. 965, 1019 (2003) (raising the textual argument that "a communication that does not attempt to persuade a governmental decision-maker to do something is not a petition and is outside the scope of the Noerr principle").

${ }^{365}$ Cardtoons, L.C. v. Major League Baseball Players Ass’n, 208 F.3d 885, 892 (10th Cir. 2000) (en banc).

${ }^{366}$ See, e.g., 1 Areeda \& Hovenkamp, supra note 199, ๆ 205f, at 302 (“Although a mere threat directed at one's competitor to sue or to seek administrative relief does not involve or 'petition' the government, it would be anomalous and socially counterproductive to protect the right to sue but not the right to threaten suit.”).

${ }^{367}$ See John T. Delacourt, Protecting Competition by Narrowing Noerr: A Reply, 18 Antitrust 77, 78 (2003). 
ing an attorney to investigate the infringement allegations. ${ }^{368}$ Punishing patent holders who send those types of letters will not discourage or inhibit patent holders who make assertions of patent infringement in a legitimate attempt to avoid going to court.

This is not to say that patent holders should have no leeway when making infringement allegations. Indeed, the law should protect patent holders who make plausible but unsuccessful allegations of infringement, so long as the allegations are made in a way that is neither unfair nor deceptive. Fortunately, those goals can be attained without granting patent holders the broad immunity that Noerr confers on antitrust defendants. Rather, courts can and should return to first principles: the flexible, equitable good faith standard to which the Federal Circuit's current immunity doctrine traces its roots. As discussed, pre-Federal Circuit decisions allowed patent holders to make legitimate assertions of patent infringement while also permitting injunctions against patent holders based on their bad faith. That bad faith standard included both subjective considerations (such as the patent holder's lack of intent to file a threatened infringement suit) and objective considerations (such as the weakness of the infringement claim on the merits). Returning to this flexible standard would allow governments, both state and federal, to condemn the assertions of infringement that are most troublesome.

For example, a patent holder who threatens numerous end users with an infringement suit, with no intent to actually file suit, could be subjected to civil liability. An illustrative pre-Federal Circuit case is Adriance, Platt \& Co. v. National Harrow Co., in which the patent holder sent letters to the plaintiff's customers, claiming that it would "sue all dealers" who purchased the allegedly infringing goods manufactured by the plaintiff and that it was "constantly bringing suits wherever these dealers are found" when, in fact, it had never actually filed an infringement suit. ${ }^{369}$ The Second Circuit enjoined the patent holder from sending additional letters, noting that the previous letters "were inspired by a purpose to intimidate the [plaintiff's] customers, and [to] coerce the [plaintiff], by injuring its business, into becoming a licensee of the defendant." 370 "In view of its failure to bring an infringement action," the

\footnotetext{
${ }^{368}$ Cf. Elhauge, supra note 194, at 1215 (arguing that Noerr immunity should not protect "restraints resulting from activities that [are] ... separate from [a] valid effort to influence the government”).

${ }^{369} 121$ F. 827, 829-30 (2d Cir. 1903).

${ }^{370}$ Id. at 830 .
} 
court wrote, "the defendant cannot shelter itself behind the theory that its circulars and letters were merely legitimate notices of its rights." 371

Similarly, a patent holder who makes allegations of infringement without having investigated the supposed acts of infringement-as is almost certainly the case when a patent holder sends letters to thousands of alleged infringers-would not be entitled to immunity under the traditional bad faith standard. As the Federal Circuit noted in Mallinckrodt, under that standard, courts had enjoined infringement notices "when the patentee sent notices indiscriminately to all members of the trade." ${ }^{372}$ In more recent cases, however, the Federal Circuit has prohibited plaintiffs from relying on the patent holder's lack of investigation into the alleged infringement to prove bad faith. ${ }^{373}$

Furthermore, a return to the traditional standard would free courts from the Noerr-based principle, embraced in Innovatio and Activision, that any false statement must relate to the issues of validity or infringement to strip a patent holder of immunity. Pre-Federal Circuit decisions, for example, condemned patent holders who circulated notices that "falsely stated and pretended that certain patents owned by the [patent holder] ha[d] been adjudicated and sustained in contested cases." ${ }^{374}$ This change in the law would enable private plaintiffs and government law enforcers, such as the FTC and state attorneys general, to impose civil liability on unscrupulous patent holders without having to take the diffi-

\footnotetext{
${ }^{371}$ Id.

${ }^{372}$ Mallinckrodt, Inc. v. Medipart, Inc., 976 F.2d 700, 710 (Fed. Cir. 1992) (citing Int'l Indus. \& Devs. v. Farbach Chem. Co., 241 F.2d 246 (6th Cir. 1957)); see also United States v. Besser Mfg. Co., 96 F. Supp. 304, 312 (E.D. Mich. 1951) (imposing liability on a patent holder in part because "there were two or three instances where suit was threatened involving machines that agents of defendants had never even seen”).

${ }^{373}$ See, e.g., Dominant Semiconductors Sdn. Bhd. v. OSRAM GmbH, 524 F.3d 1254, 1263-64 (Fed. Cir. 2008) (discussing the plaintiff's arguments that the patent holder did not test the accused products, construe the claims of the patents, or "consider[] an earlier analysis of [the plaintiff's] products suggesting that infringement was an open question," noting that the plaintiff's arguments "might be probative of subjective baselessness, but they do not help to show that a jury reasonably could find that [the plaintiff] could meet its burden of proving by clear and convincing evidence that [the defendant's] infringement allegations were objectively baseless").

${ }^{374}$ A.B. Farquhar Co. v. Nat'l Harrow Co., 102 F. 714, 715 (3d Cir. 1900); accord Gerosa v. Apco Mfg. Co., 299 F. 19, 26 (1st Cir. 1924) (affirming order granting an injunction and damages to a defendant in an infringement case where the patent holder had "sen[t] circulars to the trade and to a great number of defendant's customers ... with the evident purpose of representing that [it] had won [previous infringement] suits,” when, in fact, the suits had
} been settled). 
cult additional step of disproving the merits of the underlying infringement claim.

\section{B. Objections and Responses}

One might reasonably be concerned that allowing governments more leeway to regulate assertions of patent infringement would compromise the rights of patent holders with legitimate claims. But, to be clear, the cases in which courts should find bad faith are exceptional. In the past, those cases often involved statements by patent holders that were plainly false, ${ }^{375}$ legal claims that were objectively weak on the merits, ${ }^{376}$ or both. Thus, a good faith immunity standard would provide ample protection for patent holders to provide legitimate notice of their patent rights.

One might also object that state laws regulating unfair or deceptive patent enforcement are unnecessary because shake-down settlements are not particularly common. For instance, a draft complaint prepared by the FTC as part of its investigation into MPHJ claimed that, of the over 16,000 businesses that received a letter, only seventeen purchased licenses. ${ }^{377}$ If few people are in fact harmed by this activity, then it may not be worth rewriting the law. That said, MPHJ's campaign is an extreme example because its dubious enforcement tactics were so heavily publicized, making it less likely that recipients would feel compelled to purchase a license. Many patent holders target relatively unsophisticated organizations on a smaller scale, ${ }^{378}$ and some of those patent holders actually pursue litigation in court as a source of further leverage. ${ }^{379}$ Data about patent settlements is hard to come by, in part because targets are usually not eager to publicize the fact that they have been accused of infringement or that they have paid to make the allegations go away. ${ }^{380}$

\footnotetext{
${ }^{375}$ See supra notes 369-73 and accompanying text.

${ }^{376}$ See, e.g., Int'l Indus. \& Devs. v. Farbach Chem. Co., 145 F. Supp. 34, 36 (S.D. Ohio 1956).

377 Complaint exhibit F, at 9, MPHJ Tech. Invs., LLC v. FTC, No. 6:14-cv-11 (W.D. Tex. Jan. 13, 2014), available at http://cdn.arstechnica.net/wp-content/uploads/2014/01/FTC-MPHJ. draf_.complaint.pdf (excerpting FTC draft complaint against MPHJ).

${ }^{37 \overline{8}}$ Hearing on the Impact of Patent Assertion Entities on Innovation and the Economy Before the Subcomm. on Oversight \& Investigations of the H. Comm. on Energy \& Commerce, 113th Cong. 6 (Nov. 14, 2013) (statement of Charles Duan, Director of Patent Reform Project, Public Knowledge), available at https://www.publicknowledge.org/files/Charles\%20Patent\%20 Testimony\%20Final.pdf.

${ }^{379}$ Chien \& Reines, supra note 13 , at 235-37.

${ }^{380}$ Boushie et al., supra note 70 .
} 
Furthermore, for patent disputes that are resolved out of court, there is no threat of judicial sanction for frivolous or abusive tactics, ${ }^{381}$ and legislative proposals to award prevailing parties their attorneys' fees provide little help. ${ }^{382}$ Thus, allowing governments to condemn unfair or deceptive enforcement practices fills a regulatory gap, even if it is difficult to quantify the harm from those practices. ${ }^{383}$

One might also suggest that the new state statutes are largely symbolic because they merely replicate existing laws, as illustrated by Vermont's suit against MPHJ under the state's pre-existing consumer protection statute. ${ }^{384}$ Although there is overlap between pre-existing law and the new statutes, patent-specific statutes are not superfluous. State statutes generally prohibiting unfair or deceptive acts or practices sometimes protect individuals only, not the business entities that are likely to be the targets of patent demand letters. ${ }^{385}$ Moreover, statutes prohibiting deceptive trade practices do not uniformly allow the plaintiff to recover damages, ${ }^{386}$ as is possible under most of the new patent-specific statutes. In addition, deceptive trade practice statutes frequently limit the court's ability to award attorneys' fees, ${ }^{387}$ unlike the new statutes, most of which simply state that the court "may award" fees. Although a comprehensive examination of unfair and deceptive trade practice law is beyond this Article's scope, the point is that statutes aimed specifically at patent enforcement could add meaningful content.

\footnotetext{
${ }^{381}$ Cf. Fed. R. Civ. P. 11 (permitting judicial sanctions for frivolous or abusive court filings).

${ }^{382}$ See, e.g., Innovation Act, H.R. 9, 114th Cong. § 3(b) (2015); see also Leah Chan Grinvald, Policing the Cease-and-Desist Letter, 49 U.S.F. L. Rev. (forthcoming 2015) (manuscript at 10), available at http://ssrn.com/abstract=2515455 (noting that most intellectual property disputes are resolved out of court).

${ }^{383}$ There is, of course, a rich literature attempting to quantify the social harm of NPEs more generally. As a small sample, see Bessen \& Meurer, supra note 14, at 389-406; Colleen Chien, Startups and Patent Trolls, 17 Stan. Tech. L. Rev. 461, 463-65 (2014); James Bessen, Jennifer Ford \& Michael J. Meurer, The Private and Social Costs of Patent Trolls, Regulation, Winter 2011-12, at 26.

384 Johnson, supra note 30, at 2072.

${ }^{385}$ See, e.g., In re Ford Motor Co. E-350 Van Prods. Liab. Litig., No. CIV-03-4558, 2008 WL 4126264, at*22 (D.N.J. Sept. 2, 2008) (applying the Alabama Deceptive Trade Practices Act); Joy A. McElroy, M.D., Inc. v. Maryl Grp., 114 P.3d 929, 941 (Haw. Ct. App. 2005) (applying Hawaii statute condemning "unfair or deceptive acts or practices”); see also Nat'l Consumer Law Ctr., Unfair and Deceptive Acts and Practices 138-39 n.1864 (8th ed. 2012) (collecting cases).

${ }^{386}$ See Uniform Deceptive Trade Practices Act § 3(a) (1966) (providing for injunctions only).

${ }^{387}$ See id. § 3(b) (permitting award of attorneys' fees only if the defendant "willfully engaged in the trade practice knowing it to be deceptive”).
} 


\section{CONCLUSION}

The objective of this Article has not been to argue that regulation of patent enforcement should be left to the states. ${ }^{388}$ Rather, the aim has been to highlight that, under Federal Circuit law, no government bodystate or federal; legislative, administrative, or judicial—can meaningfully police dubious tactics of patent enforcement, and to argue that the broad immunity enjoyed by patent holders is unwarranted. But is there a case for greater state involvement in regulating patent enforcement? State-by-state regulation would certainly inject legal disuniformity into a patent system in which uniformity is highly valued. ${ }^{389}$ Accordingly, the proposed federal TROL Act would expressly preempt the new state statutes regulating patent enforcement. ${ }^{390}$ But the bill would not bring about perfect uniformity because it would not preempt "any State consumer protection law, any State law relating to acts of fraud or deception, [or] any State trespass, contract, or tort law,"391 all of which have been and would continue to be relied on to challenge acts of patent enforcement.

Moreover, legal uniformity is not a goal that should be pursued at all costs, ${ }^{392}$ for any fragmentation that flows from state-by-state regulation could actually help combat unscrupulous enforcement tactics. Bottom feeders such as MPHJ and Innovatio attempt to capitalize on the fact that litigating a patent suit is expensive. By some estimates, it costs nearly a million dollars to defend against even the smallest infringement suit. ${ }^{393}$

\footnotetext{
${ }^{388}$ For an analysis of whether unfair and deceptive acts of patent enforcement should be regulated by the states or by the federal government, see Hearing on Patent Demand Letter Practices and Solutions Before the H. Subcomm. on Commerce, Mfg. \& Trade of the H. Comm. on Energy \& Commerce, 114th Cong. 18-24 (Feb. 26, 2015) (statement of Paul R. Gugliuzza, Associate Professor of Law, Boston Univ. Sch. of Law), available at http://docs.house.gov/ meetings/IF/IF17/20150226/103029/HHRG-114-IF17-Wstate-GugliuzzaP-20150226.pdf (suggesting that demand letter regulation should "emphasize[] the respective strengths of state governments and the federal government").

${ }^{389}$ See Gugliuzza, supra note 24, at 17-27 (describing how the policy of uniformity drives important decisions about patent law and the patent system).

${ }^{390}$ Targeting Rogue and Opaque Letters Act of 2015, H.R. 2045, 114th Cong. § 4(a)(1) (preempting "any law, rule, regulation, requirement, standard, or other provision having the force and effect of law of any State ... expressly relating to the transmission or contents of communications relating to the assertion of patent rights”); accord Support Technology and Research for Our Nation's Growth Patents Act of 2015, S. 632, 114th Cong. § 204(a)(1).

${ }^{391}$ H.R. 2045 § 4(a)(2); accord S. 632 § 204(a)(2).

${ }^{392}$ Cf. Lisa Larrimore Ouellette, Patent Experimentalism, 101 Va. L. Rev. 65, 68 (2015) (arguing that empirical progress in patent policy depends on greater legal diversity).

${ }^{393}$ Am. Intellectual Prop. Law Ass'n, 2013 Report of the Economic Survey (2013), available at http://www.patentinsurance.com/custdocs/2013AIPLA\%20Survey.pdf.
} 
It is therefore often cheaper for defendants to settle rather than to fight. State-by-state regulation has the potential to turn the table. Rather than defending against, say, one unfair competition suit brought by the FTC, a patent holder might instead need to defend against multiple lawsuits in multiple states, brought by both private plaintiffs and state attorneys general. MPHJ, for example, has been sued by the state of Vermont and has been investigated by the FTC and by attorneys general in at least three states. The prospect of ex post litigation on multiple fronts could be a significant deterrent to unfair or deceptive assertions of patent infringement. 